\title{
Reassessment of Al-Ce and Al-Nd Binary Systems Supported by Critical Experiments and First-Principles Energy Calculations
}

\author{
MICHAEL C. GAO, NECIP ÜNLÜ, G.J. SHIFLET, MAREK MIHALKOVIC, \\ and MICHAEL WIDOM
}

The present study reinvestigates the Al-Ce and Al-Nd phase diagrams and reoptimizes their thermodynamics using the CALPHAD method. First-principles energy calculations play an important role in terms of sublattice formalism and phase-stability prediction, demonstrating that they should be effectively integrated into experimental investigations and thermodynamic assessments. Specifically, current experimental results and theoretical calculations show that $\mathrm{Al}_{2} \mathrm{Nd}$ (or $\mathrm{Al}_{2} \mathrm{Ce}$ ) should be treated as a stoichiometric compound phase rather than as the solution phase that was proposed in previous studies. Further, a new compound, $\mathrm{AlCe}_{2}$, is found stable at high temperatures $\left(648^{\circ} \mathrm{C}\right.$ to $\left.775^{\circ} \mathrm{C}\right)$ in the $\mathrm{Al}-\mathrm{Ce}$ system. It forms through a peritectic reaction of liquid and $\mathrm{AlCe}$ phases at $775^{\circ} \mathrm{C}$, and decomposes into $\mathrm{AlCe}$ and $\beta \mathrm{AlCe}_{3}$ at $648{ }^{\circ} \mathrm{C}$ and below. Since the $\mathrm{AlCe}_{2}$ phase is not retained at room temperature by quenching experiments, it is suggested that $\mathrm{AlCe}_{2}$ may be isostructural with the previously known compound $\mathrm{AlNd}_{2}$ $(o P 12)$. Based on current differential thermal analysis (DTA) measurements and theoretical calculations, it is also proposed that there is an $\alpha / \beta \mathrm{Al}_{3} \mathrm{Ce}$ polymorphous transition occurring at $973{ }^{\circ} \mathrm{C}$ in the $\mathrm{Al}-\mathrm{Ce}$ system and an $\alpha / \beta \mathrm{Al}_{3} \mathrm{Nd}$ polymorphous transition occurring at $888^{\circ} \mathrm{C}$ in the $\mathrm{Al}-\mathrm{Nd}$ system. The $\beta \mathrm{Al}_{3} \mathrm{RE}$ phase may be isostructural with $\beta \mathrm{Al}_{3} \mathrm{Y}(h P 12)$. Finally, the previously described $\beta \mathrm{Al}_{11} \mathrm{RE}_{3}$ phase (rare earth elements $(\mathrm{RE})=\mathrm{La}, \mathrm{Ce}, \mathrm{Nd}$, or $\mathrm{Pr})$ is proposed to have a stoichiometry of $\mathrm{Al}_{4} \mathrm{RE}(t I 10)$, based on direct evidence from differential scanning calorimetry (DSC) measurements.

\section{INTRODUCTION}

BECAUSE of their promise in engineering applications and fundamental scientific interest, metallic glass (MG) has more often been the subject of research recently. In particular, Al-based $\mathrm{MG}^{[1,2]}$ receives attention, based in part, on its high specific strength. Glass formation can be achieved on both the Al-rich and $\mathrm{RE}$-rich sides for Al-RE systems ( $\mathrm{RE}=$ rare earth elements). Similar glass formation phenomena occur in Al-TM-RE ternary systems (TM $=$ transition metals). ${ }^{[1,2]}$ Glass formation is difficult in the Al-rich corner, while bulk MG is possible in the RE-rich corner, with a slow cooling rate. Because underlying thermodynamics play an important role in amorphorization during cooling, accurate phase diagrams and reasonable thermodynamic parameters for all the equilibrium and metastable phases must be determined consistently. Consequently, the $\mathrm{Al}-\mathrm{Co}-\mathrm{Ce}$ and $\mathrm{Al}-$ $\mathrm{Ni}-\mathrm{Nd}$ systems in their Al-rich corner are being investigated by the current authors, by integrating critical experiments, firstprinciples energy calculations, and CALPHAD modeling. The present article begins with results on the Al-RE binaries.

A number of authors experimentally investigated and thermodynamically studied and assessed the Al-Ce and Al-Nd

MICHAEL C. GAO, Research Associate, formerly with the Department of Materials Science and Engineering, University of Virginia, is with Department of Materials Science and Engineering, Carnegie Mellon University, Pittsburgh, PA 15213. NECIP ÜNLÜ, Research Associate, and G.J. SHIFLET, Professor, are with the Department of Materials Science and Engineering, University of Virginia, Charlottesville, VA 22904-4745. MAREK MIHALKOVIC, formerly Visiting Scholar, Department of Physics, Carnegie Mellon University, is with the Institute of Physics, Slovak Academy of Sciences, 84511 Bratislava, Slovakia. MICHAEL WIDOM, Professor, is with the Department of Physics, Carnegie Mellon University.

Manuscript submitted April 25, 2005. binary systems. ${ }^{[3-26]}$ Detailed reviews and bibliographic information can be found in References 11, 18, 21, and 22. The $\mathrm{Al}_{2} \mathrm{RE}(c F 24)$ is a Laves phase $\left(\mathrm{C} 15\right.$, prototype $\left.\mathrm{Cu}_{2} \mathrm{Mg}\right)$; in order to be compatible with the Laves phase description in other systems, Cacciamani et al. ${ }^{[18,20]}$ modeled it as an ordered two-sublattice solution phase (i.e., $\left.(\mathrm{Al}, \mathrm{RE})_{2}(\mathrm{Al}, \mathrm{RE})\right)$, in which $\mathrm{Al}$ and $\mathrm{RE}$ atoms can mix with each other in each sublattice. In this model, both $\mathrm{Al}_{2} \mathrm{Nd}$ and $\mathrm{Al}_{2} \mathrm{Ce}$ exhibit appreciable solubility ranges at high temperatures (Figure 1), but experimental evidence is absent. In the present study, such a solution trend in $c F 24$ (if any) is analyzed using first-principles energy calculations and thermal analysis measurements. Further, thermal measurements were performed for the whole $\mathrm{Al}-\mathrm{Ce}$ binary and the Al-rich Al-Nd systems, and some new phases will be reported herein, namely, $\mathrm{AlCe}_{2}(o P 12), \beta \mathrm{Al}_{3} \mathrm{Ce}(h P 12)$, and $\beta \mathrm{Al}_{3} \mathrm{Nd}(h P 12)$, which are stable. In this study, first-principle energy calculations were successfully integrated into the current experimental investigation and CALPHAD modeling, and it is suggested that such integration should be applied extensively into phase diagram research. Based upon first-hand experimental data, supported by theoretical predictions together with literature information, both the $\mathrm{Al}-\mathrm{Ce}$ and $\mathrm{Al}-\mathrm{Nd}$ systems were thermodynamically optimized using the PARROT module of the commercial THERMO-CALC* ${ }^{*}$ software. ${ }^{[27]}$

*THERMO-CALC is a trademark Thermo-Calc, Stockholm, Sweden.

\section{EXPERIMENTAL PROCEDURES AND RESULTS}

All alloys were synthesized by arc-melting pieces of Al (99.999 pct purity, all are in atomic percentage unless specified otherwise) and $\mathrm{Nd}$ (99.9 pct) or Ce (99.9 pct) on a water- 

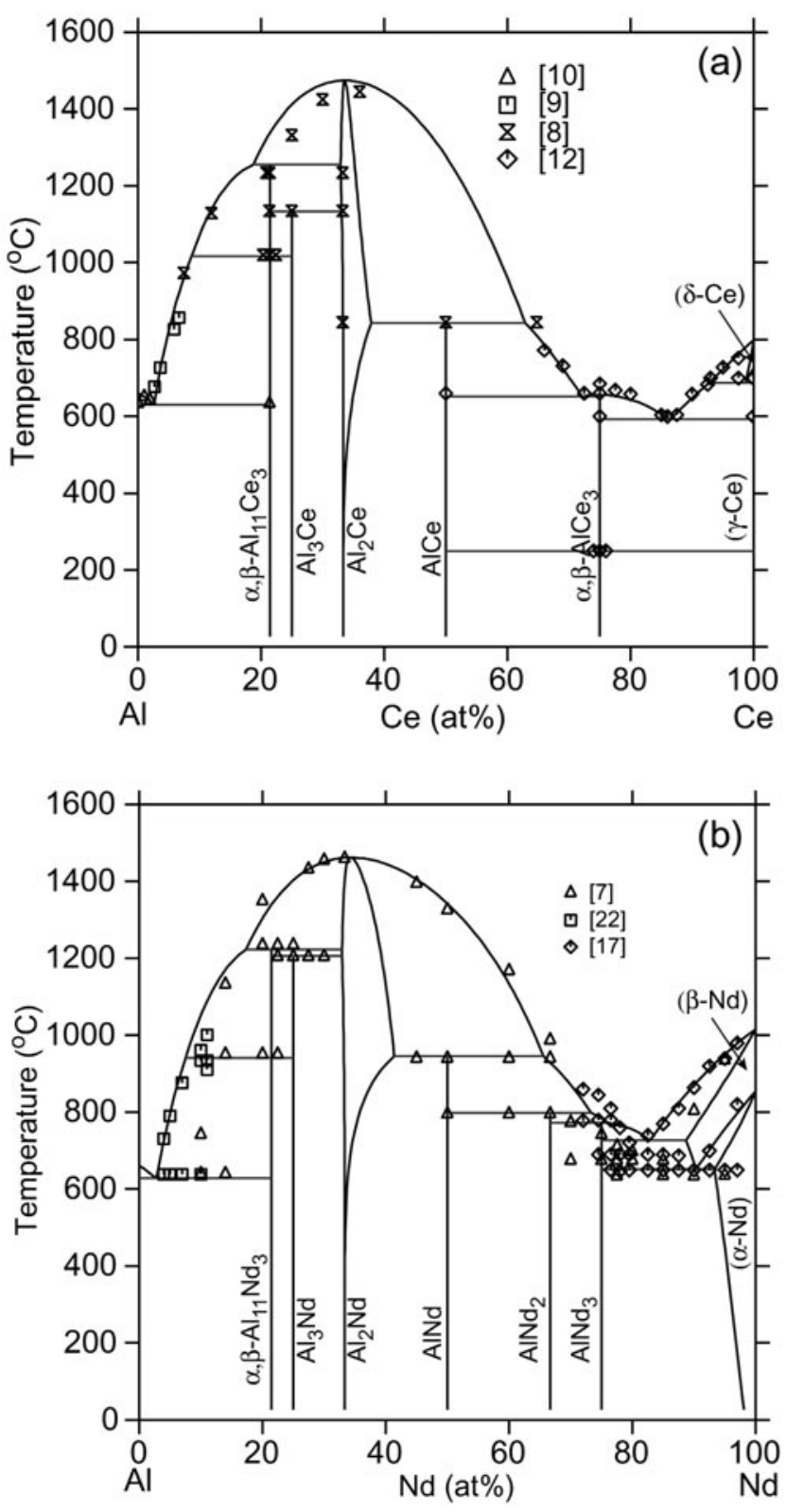

Fig. 1-(a) The Al-Ce and (b) Al-Nd binary phase diagrams assessed by Cacciamani and Ferro. ${ }^{[18]}$

cooled copper hearth, using a tungsten electrode in an argon atmosphere. The ingots, about 2 to 5 grams, were remelted 4 to 5 times to ensure chemical homogeneity, and cooled to room temperature inside the arc furnace. The weight loss is about $1 \mathrm{wt}$ pct. Differential thermal analysis (DTA) was performed on all the as-arc-melted samples. The DTA measurements were originally performed using a PERKIN-ELMER* DTA7

*PERKIN-ELMER is a trademark of Perkin-Elmer, Wellesley, MA.

for several alloys at a heating/cooling rate of $10 \mathrm{~K} / \mathrm{min}$, and later using a NETZSCH* DSC404C with a DTA carrier at a heating

*NETZSCH is a trademark of Erich Netzsch GmbH \& Co. Holding KG, Selb, Germany.

rate of $20{ }^{\circ} \mathrm{C} / \mathrm{min}$ that also has the capability of controlled atmosphere, which therefore prevents oxidation. The sample

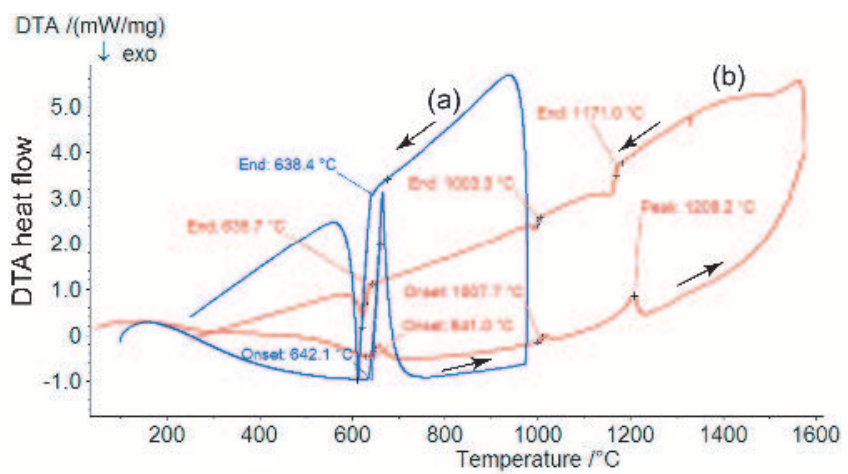

Fig. 2-The DTA plots for alloys (a) $\mathrm{Al}_{97.4} \mathrm{Ce}_{2.6}$ and $(b) \mathrm{Al}_{82.5} \mathrm{Ce}_{17.5}$, at heating and cooling rates of $20^{\circ} \mathrm{C} / \mathrm{min}$. It can be concluded that $\mathrm{Al}_{97.4} \mathrm{Ce}_{2.6}$ is a eutectic composition, and the eutectic reaction Liq $\leftrightarrow \mathrm{Al}_{11} \mathrm{Ce}_{3}+\mathrm{Al}$ occurs at $\sim 641{ }^{\circ} \mathrm{C}$. There are three reactions observed in (b). The first is the same eutectic reaction as in (a), the second is the reaction $\mathrm{Al}_{4} \mathrm{Ce} \leftrightarrow$ $\mathrm{Liq}+\mathrm{Al}_{11} \mathrm{Ce}_{3}$, and the third is the final melting. The spike that occurs at $\sim 1350{ }^{\circ} \mathrm{C}$ in (b) is an artificial signal from the DTA unit.

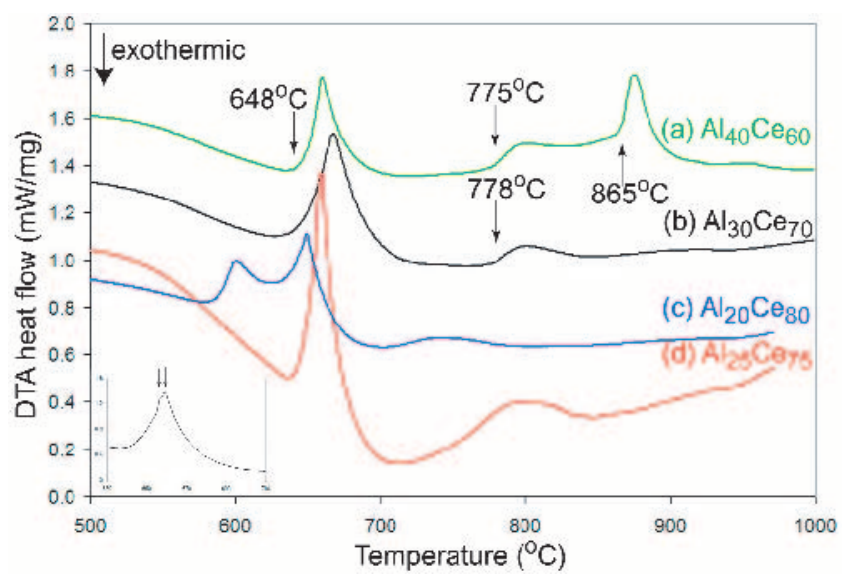

Fig. 3-The DTA plots for (a) $\mathrm{Al}_{40} \mathrm{Ce}_{60}$, (b) $\mathrm{Al}_{30} \mathrm{Ce}_{70},(c) \mathrm{Al}_{20} \mathrm{Ce}_{80}$, and (d) $\mathrm{Al}_{25} \mathrm{Ce}_{75}$, at a heating rate of $20{ }^{\circ} \mathrm{C} / \mathrm{min}$. The inset is the first peak of (d) $\mathrm{Al}_{25} \mathrm{Ce}_{75}$, where two tightly overlapping peaks, marked by the arrows, correspond to the reactions of $\mathrm{AlCe}_{2} \leftrightarrow \beta \mathrm{AlCe}_{3}+\mathrm{AlCe}$ and $\mathrm{AlCe}_{2}+$ $\mathrm{Liq} \leftrightarrow \beta \mathrm{AlCe}_{3}$. The bulk chemistry of (d) is slightly shifted from its nominal value to the Al-rich side.

chamber of the DSC404 was initially evacuated to a vacuum of $1.0 \times 10^{-5}$ torr and then backfilled with flowing high-purity argon (grade 5). The Netzsch DTA carrier was calibrated with 7 standards, including $\mathrm{Sn}, \mathrm{Bi}, \mathrm{Zn}, \mathrm{Al}, \mathrm{Ag}, \mathrm{Au}$, and $\mathrm{Ni}$, to ensure that the measurement would be accurate over a wide temperature range of $100{ }^{\circ} \mathrm{C}$ to $1600{ }^{\circ} \mathrm{C}$. The overall accuracy of the DTA measurement is $\pm 3{ }^{\circ} \mathrm{C}$. A typical DTA plot is shown in Figure 2, for alloys $\mathrm{Al}_{97.4} \mathrm{Ce}_{2.6}$ and $\mathrm{Al}_{82.5} \mathrm{Ce}_{17.5}$. Alloy $\mathrm{Al}_{97.4} \mathrm{Ce}_{2.6}$ was chosen to verify the eutectic point of reaction Liq $\leftrightarrow$ $\mathrm{Al}_{11} \mathrm{Ce}_{3}+\mathrm{Al}$ (Liq refers to the liquid phase). The DTA scan was repeated over a series of temperature ranges (only one scan is shown in Figure 2 for $\mathrm{Al}_{97.4} \mathrm{Ce}_{2.6}$ ), and there was only one reproducible thermal event observed; thus, it was concluded that the eutectic point is 2.6 at. pct $\mathrm{Ce}$ at $\sim 641{ }^{\circ} \mathrm{C}$. In addition to the same eutectic reaction as in (a), alloy $\mathrm{Al}_{82.5} \mathrm{Ce}_{17.5}$ exhibits a second reaction, $\mathrm{Al}_{4} \mathrm{Ce} \leftrightarrow \mathrm{Liq}+\mathrm{Al}_{11} \mathrm{Ce}_{3}$, and a final melting. Note that for each thermal event observed during a heating cycle, there is a corresponding thermal event observed during the cooling cycle that occurs at a lower temperature (i.e., 
the onset temperature), because of the requirement of undercooling for nucleation during phase transformations.

Figure 3 shows the DTA plot for four alloys, namely, (a) $\mathrm{Al}_{40} \mathrm{Ce}_{60}$, (b) $\mathrm{Al}_{30} \mathrm{Ce}_{70}$, (c) $\mathrm{Al}_{20} \mathrm{Ce}_{80}$, and (d) $\mathrm{Al}_{25} \mathrm{Ce}_{75}$, during the heating segment. Three main thermal events occur in $\mathrm{Al}_{40} \mathrm{Ce}_{60}$ (Figure 3(a)). The first corresponds to the decomposition of $\mathrm{BAlCe}_{3}$ into $\mathrm{AlCe}$ and $\mathrm{AlCe}_{2}$ at $\sim 648{ }^{\circ} \mathrm{C}$; the second is the peritectic melting of $\mathrm{AlCe}_{2}$ into $\mathrm{AlCe}$ and liquid at $\sim 775{ }^{\circ} \mathrm{C}$; the third is the peritectic melting of $\mathrm{AlCe}$ into $\mathrm{Al}_{2} \mathrm{Ce}$ and liquid at $\sim 865{ }^{\circ} \mathrm{C}$. The final melting signal is very weak and the liquidus temperature is estimated to be $958{ }^{\circ} \mathrm{C}$. Alloy $\mathrm{Al}_{45} \mathrm{Ce}_{55}$ exhibits a DTA plot similar to that of $\mathrm{Al}_{40} \mathrm{Ce}_{60}$, with three main peaks that occur at temperatures almost identical to $\mathrm{Al}_{40} \mathrm{Ce}_{60}$, plus a final melting peak. Such identical thermal histories for both alloys indicate that they must be chemically located within the same phase fields with rising temperature. Note that the second thermal event for both alloys was not reported in the literature; perhaps this is the reason why $\mathrm{AlCe}_{2}$ was not identified. Only two main thermal events occur in $\mathrm{Al}_{30} \mathrm{Ce}_{70}$ (Figure 3(b)). The first peak is broad and is believed to contain two overlapping reactions, i.e., $\mathrm{AlCe}_{2} \leftrightarrow \beta \mathrm{AlCe}_{3}+\mathrm{AlCe}$ and $\mathrm{AlCe}_{2}+$ $\mathrm{Liq} \leftrightarrow \mathrm{AlCe}_{3}$. The second event has a well-defined onset at $\sim 778{ }^{\circ} \mathrm{C}$, which is almost identical to the onset of the second thermal event of alloys $\mathrm{Al}_{40} \mathrm{Ce}_{60}$ and $\mathrm{Al}_{45} \mathrm{Ce}_{55}$, within the experimental error range. Based on the DTA measurements of these three alloys, the peritectic reaction of $\mathrm{AlCe}+$ $\mathrm{Liq} \leftrightarrow \mathrm{AlCe}_{2}$ at $\sim 775^{\circ} \mathrm{C}$ can be reasonably justified. The perectic point is estimated to be slightly richer in $\mathrm{Ce}$ than is $\mathrm{Al}_{30} \mathrm{Ce}_{70}$, the final melting point of which is about $802{ }^{\circ} \mathrm{C}$. Note that $\mathrm{Al}_{30} \mathrm{Ce}_{70}$ was reported as the eutectic point of the reaction $\mathrm{Liq} \leftrightarrow \mathrm{AlCe}+\beta \mathrm{AlCe}_{3},{ }^{[8]}$ while the same reaction was reported to occur at a composition of $\mathrm{Al}_{27.5} \mathrm{Ce}_{72.5} \cdot{ }^{[17]}$ Alloy $\mathrm{Al}_{20} \mathrm{Ce}_{80}$ (Figure 3(c)) has two main (slightly overlapping) peaks and a final shallow melting peak. The first peak is the eutectic reaction of $\mathrm{Liq} \leftrightarrow \gamma \mathrm{Ce}+\beta \mathrm{AlCe}_{3}$ occurring at $590{ }^{\circ} \mathrm{C}$, and the second peak is believed to be the peritectic reaction of $\mathrm{AlCe}_{2}+\mathrm{Liq} \leftrightarrow \beta \mathrm{AlCe}_{3}$. The peritectic point is estimated as slightly over the composition $\mathrm{Al}_{20} \mathrm{Ce}_{80}$. The first peak of alloy $\mathrm{Al}_{25} \mathrm{Ce}_{75}$ (Figure $3(\mathrm{~d})$ ) appears sharp; however, it actually consists of two overlapping peaks. (It is enlarged in Figure 3(e), inset.) This implies that the bulk-alloy chemistry is slightly off its nominal value. But the more important conclusion is that the reaction $\mathrm{AlCe}_{2}+\mathrm{Liq} \leftrightarrow \beta \mathrm{AlCe}_{3}$ occurs at a slightly higher temperature than does that of $\mathrm{AlCe}_{2} \leftrightarrow \beta \mathrm{AlCe}_{3}+\mathrm{AlCe}$ at $647^{\circ} \mathrm{C}$, and that these two temperatures are almost too close for DTA to differentiate clearly. In summary, current DTA measurements on the Ce-rich alloys support that there is a new phase $\mathrm{AlCe}_{2}$, stable at a narrow temperature range of $648{ }^{\circ} \mathrm{C}$ to $775^{\circ} \mathrm{C}$. Note that $\mathrm{Al}_{25} \mathrm{Ce}_{75}$ was reported to melt congruently at $655{ }^{\circ} \mathrm{C}$ by Buschow et al. ${ }^{[8]}$ this is fairly close to the present value. On the other hand, Saccone et al. reported that $\mathrm{Al}_{25} \mathrm{Ce}_{75}$ melted congruently at $685{ }^{\circ} \mathrm{C}$, ${ }^{[17]}$ but they also reported another peak at $600{ }^{\circ} \mathrm{C}$ for this alloy. ${ }^{[17]}$

Figure 4(a) shows the DSC plot for alloy $\mathrm{Al}_{11} \mathrm{Nd}_{3}$ at a heating rate of $20 \mathrm{~K} / \mathrm{min}$. The presence of a very small peak occurring at $\sim 641{ }^{\circ} \mathrm{C}$, with a heat of $0.83 \mathrm{~J} / \mathrm{g}$, indicates that its bulk chemistry is slightly shifted toward the Al-rich side; it corresponds to the eutectic reaction of $\mathrm{Liq} \leftrightarrow \mathrm{Al}+$ $\mathrm{Al}_{11} \mathrm{Nd}_{3}$. The second peak occurs at a sharp onset of $926{ }^{\circ} \mathrm{C}$ and with a heat of $12.9 \mathrm{~J} / \mathrm{g}$; it corresponds to the reaction of $\mathrm{Al}_{4} \mathrm{Nd} \leftrightarrow \mathrm{Liq}+\mathrm{Al}_{11} \mathrm{Nd}_{3}$. The third peak is shallow, with an estimated onset of $963{ }^{\circ} \mathrm{C}$ and a heat of $2.3 \mathrm{~J} / \mathrm{g}$; it corresponds to the reaction of $\mathrm{Al}_{4} \mathrm{Nd}+\beta \mathrm{Al}_{3} \mathrm{Nd} \leftrightarrow \mathrm{Al}_{11} \mathrm{Nd}_{3}$. These two thermal events directly support the idea that the reported $\beta \mathrm{Al}_{11} \mathrm{RE}_{3}{ }^{[7,8,21,22]}$ should be chemically treated as an $\mathrm{Al}_{4} \mathrm{RE}(\mathrm{RE}=\mathrm{La}, \mathrm{Ce}, \mathrm{Nd}$, or $\mathrm{Pr})$ phase; a single $\alpha / \beta \mathrm{Al}_{11} \mathrm{RE}_{3}$ polymorphous transformation just cannot explain both the second and third thermal events. This proposal gains additional support from the theoretical calculation described in Section III. The fourth peak occurs at $1216{ }^{\circ} \mathrm{C}$, with a very large amount of heat $(181 \mathrm{~J} / \mathrm{g})$. However, its first derivative (shown in the inset) indicates it may consist of two peaks, which, in fact, correspond to the reactions $\mathrm{Al}_{2} \mathrm{Nd}+\mathrm{Al}_{4} \mathrm{Nd} \leftrightarrow \mathrm{Al}_{3} \mathrm{Nd}$ and $\mathrm{Al}_{2} \mathrm{Nd}+\mathrm{Liq} \leftrightarrow$ $\mathrm{Al}_{4} \mathrm{Nd}$. (These two reactions become less overlapping in Figure 4(b), for alloy $\mathrm{Al}_{76} \mathrm{Nd}_{24}$.) The final liquidus is estimated at $1275{ }^{\circ} \mathrm{C}$, which corresponds to the melting of $\mathrm{Al}_{2} \mathrm{Nd}$. Based on this information, the recommendation is that this alloy $\mathrm{Al}_{11} \mathrm{Nd}_{3}$ (Figure 4(a)) must chemically lie between $\mathrm{Al}_{11} \mathrm{Nd}_{3}$ and $\mathrm{Al}_{4} \mathrm{Nd}$, and must be fairly close to $\mathrm{Al}_{4} \mathrm{Nd}$. For this alloy, the heat from the reaction $\mathrm{Al}_{2} \mathrm{Nd}+$ $\mathrm{Al}_{4} \mathrm{Nd} \leftrightarrow \beta \mathrm{Al}_{3} \mathrm{Nd}$ is negligible, and the large heat event (or enthalpy change) seen in the fourth peak (Figure 4(a)) results mainly from the peritectic melting of $\mathrm{Al}_{4} \mathrm{Nd}$. Figure 4(b) shows the DTA plot of alloy $\mathrm{Al}_{76} \mathrm{Nd}_{24}$ at a rate of $10 \mathrm{~K} / \mathrm{min}$, using a Perkin-Elmer DTA7. The first thermal event occurs at $888^{\circ} \mathrm{C}$ (indicated by the arrow), and may correspond to the $\alpha / \beta \mathrm{Al}_{3} \mathrm{Nd}$ phase transition. The reaction for $\mathrm{Al}_{4} \mathrm{Nd}+$ $\beta \mathrm{Al}_{3} \mathrm{Nd} \leftrightarrow \mathrm{Al}_{11} \mathrm{Nd}_{3}$ is not detected in the DTA scan; this could be due to the small amount of heat and slow kinetics for this reaction. Figure 4(c) shows the DTA plot of alloy $\mathrm{Al}_{75} \mathrm{Ce}_{25}$, obtained with a Perkin-Elmer DTA 7, with a heating/cooling rate of $10 \mathrm{~K} / \mathrm{min}$. The first thermal event shown in the heating segment corresponds to the $\alpha / \beta \mathrm{Al}_{3} \mathrm{Ce}$ polymorphous phase transition occurring at $\sim 973{ }^{\circ} \mathrm{C}$. This kind of thermal event is also observed in alloys $\mathrm{Al}_{77} \mathrm{Ce}_{23}$ and $\mathrm{Al}_{77} \mathrm{Ce}_{30}$ on their DTA scan. (Their DTA plots are not shown here; refer to Figure 7 for the DTA data points.) Based on these DTA measurements, the $\beta \mathrm{Al}_{3} \mathrm{Ce}$ and $\beta \mathrm{Al}_{3} \mathrm{Nd}$ are considered to be high-temperature, stable phases, the crystal structures of which are proposed to be isostructural with $\mathrm{Al}_{3} \mathrm{Y}(h P 12)$.

To verify the existence and crystal structure of $\mathrm{AlCe}_{2}$ and the polymorphous transformation of $\mathrm{AlCe}_{3}$ at $250{ }^{\circ} \mathrm{C},{ }^{[5]}$ two samples are chosen, i.e., $\mathrm{Al}_{45} \mathrm{Ce}_{55}$ and $\mathrm{Al}_{40} \mathrm{Ce}_{60}$, for heat treatment at $700{ }^{\circ} \mathrm{C}, 500{ }^{\circ} \mathrm{C}$, and $200{ }^{\circ} \mathrm{C}$ for 10 days each, followed by cold-water quenching. These samples are encapsulated and sealed inside silica tubes under a partial pressure of argon. Following heat treatment, the samples are ground with a series of $\mathrm{SiC}$ papers and polished using diamond paste, and finally examined in a JEOL* 6700 scan-

*JEOL is a trademark of Japan Electron Optics Ltd., Tokyo.

ning electron microscope (SEM) for microstructure analysis. Electron probe microanalysis (EPMA), using pure-element samples as external standards, is employed to perform all the chemical analysis. The accuracy of the EPMA measurements in this study is about 1 at. pct.

The polymorphous transformation of $\alpha / \beta \mathrm{AlCe}_{3}$ occurring at $250{ }^{\circ} \mathrm{C}^{[5]}$ is not detected by the DTA measurement in this study. A Perkin-Elmer DSC7, which has a much higher 

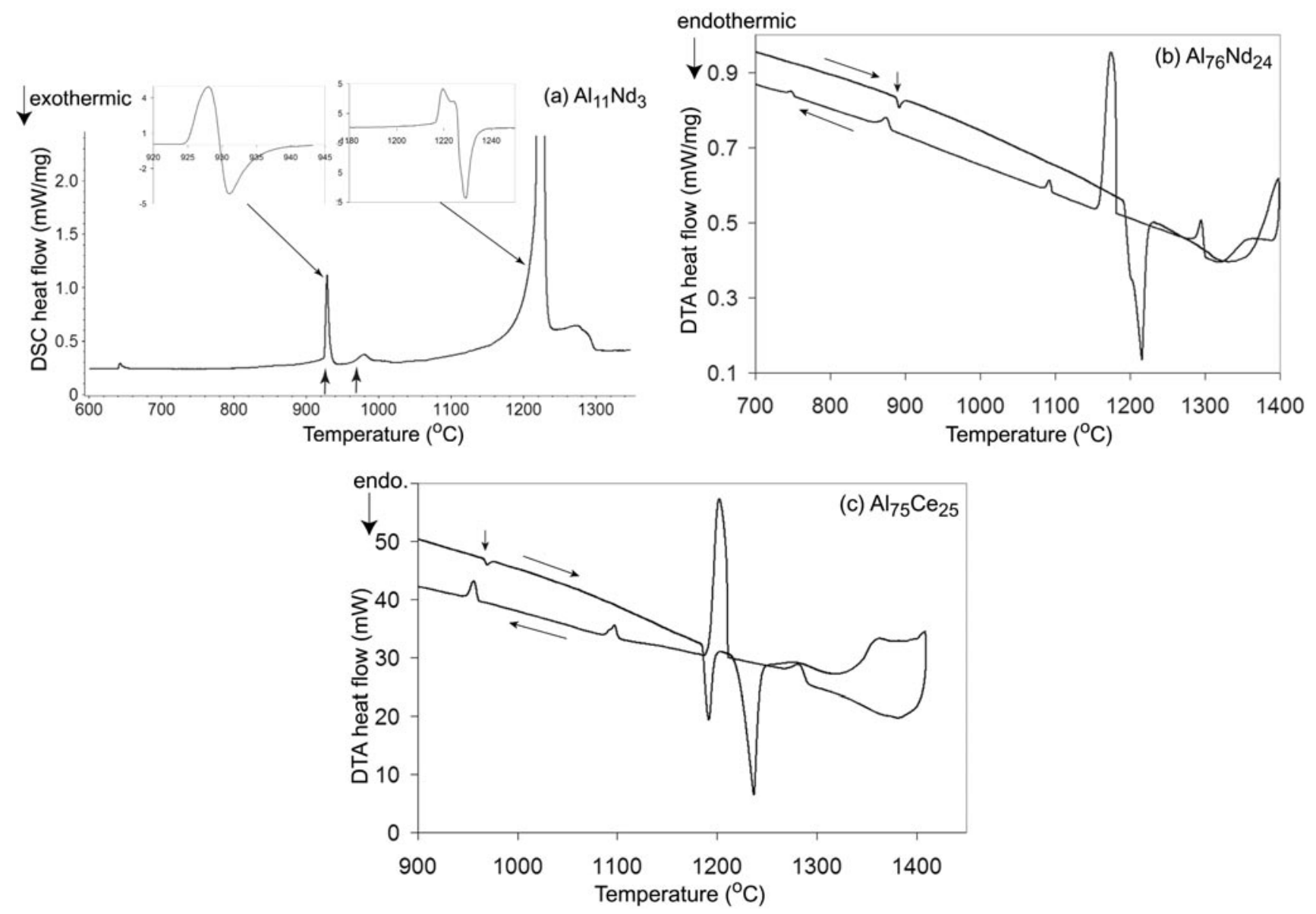

Fig. 4-(a) The DSC plot for $\mathrm{Al}_{11} \mathrm{Nd}_{3}$, at a heating rate of $20 \mathrm{~K} / \mathrm{min}$ (using a Netzsch DSC 404). There are two peaks present in the intermediate temperature regime; they are marked by the arrows, which correspond to the reactions of $\mathrm{Al}_{4} \mathrm{Nd} \leftrightarrow \mathrm{Liq}+\mathrm{Al}_{11} \mathrm{Nd}_{3}$, and $\mathrm{Al}_{4} \mathrm{Nd}+\beta \mathrm{Al}_{3} \mathrm{Nd} \leftrightarrow \mathrm{Al}_{11} \mathrm{Nd}_{3}$. They can be regarded as direct evidence supporting that the previously reported $\beta \mathrm{Al}_{11} \mathrm{RE}_{3}{ }^{[7,8,21,22]}$ should being treated as $\mathrm{Al}_{4} \mathrm{RE}(\mathrm{RE}=\mathrm{La}$,Ce,Nd,Pr) phase. The insets are the first derivatives of the peaks, which might imply two overlapping reactions, namely, $\mathrm{Al}_{2} \mathrm{Nd}+\mathrm{Al}_{4} \mathrm{Nd}_{4} \leftrightarrow \mathrm{Al}_{3} \mathrm{Nd}_{\text {and }} \mathrm{Al}_{2} \mathrm{Nd}+\mathrm{Liq}_{\mathrm{C}} \leftrightarrow \mathrm{Al}_{4} \mathrm{Nd}$. (b) The DTA plot for alloy $\mathrm{Al}_{76} \mathrm{Nd}_{24}$, at a heating/cooling rate of $10 \mathrm{~K} / \mathrm{min}$ (using a Perkin Elmer DTA 7). The arrow indicates the $\alpha / \beta \mathrm{Al}_{3} \mathrm{Nd}$ polymorphous transformation occurring at $888^{\circ} \mathrm{C}$. The reactions of $\mathrm{Al}_{2} \mathrm{Nd}+\mathrm{Al}_{4} \mathrm{Nd} \leftrightarrow \beta \mathrm{Al}_{3} \mathrm{Nd}$ and $\mathrm{Al}_{2} \mathrm{Nd}+\mathrm{Liq} \leftrightarrow \mathrm{Al}_{4} \mathrm{Nd}$ indeed overlap, and the heat from the latter is significantly larger than that from the former. The reaction of $\beta \mathrm{Al}_{3} \mathrm{Nd}+\mathrm{Al}_{4} \mathrm{Nd} \leftrightarrow \mathrm{Al}_{11} \mathrm{Nd}_{3}$ is not detected in this scan; the reason may be due to the small amount of heat and the slow kinetics for this reaction. (c) The DTA plot for alloy $\mathrm{Al}_{75} \mathrm{Ce}_{25}$, at a heating/cooling rate of $10 \mathrm{~K} / \mathrm{min}$ (using a PerkinElmer DTA 7). The arrow indicates the $\alpha / \beta \mathrm{Al}_{3} \mathrm{Ce}$ polymorphous transformation occurring at $\sim 973{ }^{\circ} \mathrm{C}$. The second peak during heating corresponds to the reaction of $\mathrm{Al}_{2} \mathrm{Ce}+\mathrm{Al}_{4} \mathrm{Ce} \leftrightarrow \beta \mathrm{Al}_{3} \mathrm{Ce}$, and the third peak corresponds to the reaction of $\mathrm{Al}_{2} \mathrm{Ce}+\mathrm{Liq} \leftrightarrow \mathrm{Al}_{4} \mathrm{Ce}$. Note that the final melting peak is very broad and that the first peak has a small amount of heat.

sensitivity in analyzing samples at a rate of $20 \mathrm{~K} / \mathrm{min}$, was then employed; again, however, no signal was detected at $250{ }^{\circ} \mathrm{C}$. The polymorphous transformation of $\alpha / \beta \mathrm{AlCe}_{3}$ is confirmed in the microstructure analysis, but the exact transformation temperature is not identified. Figures 5(a), (b), and (c) show the microstructure of alloy $\mathrm{Al}_{40} \mathrm{Ce}_{60}$ after annealing at $700{ }^{\circ} \mathrm{C}, 500{ }^{\circ} \mathrm{C}$, and $200{ }^{\circ} \mathrm{C}$, respectively, for 10 days. Three phases are present in Figures 5(a) and (b), namely, $\mathrm{AlCe}, \alpha \mathrm{AlCe}_{3}$, and $\beta \mathrm{AlCe}_{3}$. Note that $\mathrm{AlCe}_{2}$ is not retained in Figure 5(a), which indicates the fast kinetics in its decomposition during quenching. No $\beta \mathrm{AlCe}_{3}$ is detected in Figure 5(c), as expected. The microstructure of alloy $\mathrm{Al}_{45} \mathrm{Ce}_{55}$ after annealing at $700{ }^{\circ} \mathrm{C}, 500{ }^{\circ} \mathrm{C}$, and $200{ }^{\circ} \mathrm{C}$, is found to be very similar to those in alloy $\mathrm{Al}_{40} \mathrm{Ce}_{60}$ (results not shown here). The shapes of both alloys remained intact after annealing at $700{ }^{\circ} \mathrm{C}$ for 10 days, demonstrating that melting did not occur at $700{ }^{\circ} \mathrm{C}$ for these two alloys. However, according to the previously reported phase diagrams, ${ }^{[8,17]}$ both alloys should have melted into liquid $+\mathrm{AlCe}$ at $700{ }^{\circ} \mathrm{C}$. Therefore, it is suggested that the phase $\mathrm{AlCe}_{2}$ must appear as stable over a narrow temperature range of $648{ }^{\circ} \mathrm{C}$ to $775{ }^{\circ} \mathrm{C}$; its crystal structure is predicted to be isostructural of the previously known compound $\mathrm{AlNd}_{2}(o P 12)$ (Section III provides details).

\section{FIRST-PRINCIPLES ENERGY CALCULATIONS}

The two binary systems are further analyzed using firstprinciples calculations that employ the plane-wave code Vienna ab-initio simulation package (VASP) ${ }^{[28,29]}$ which solves for the electronic band structure using the electronic density functional theory. Because of the presence of rareearth elements $\mathrm{Ce}$ and $\mathrm{Nd}$, projector augmented wave (PAW) potentials ${ }^{[30]}$ are used as supplied with VASP. These are similar to pseudopotentials, except that the core levels are solved simultaneously with the valence electrons. All the f-levels are treated within the valence band and use the Perdew-Burke-Ermzerhoff (PBE) gradient approximation ${ }^{[31]}$ 

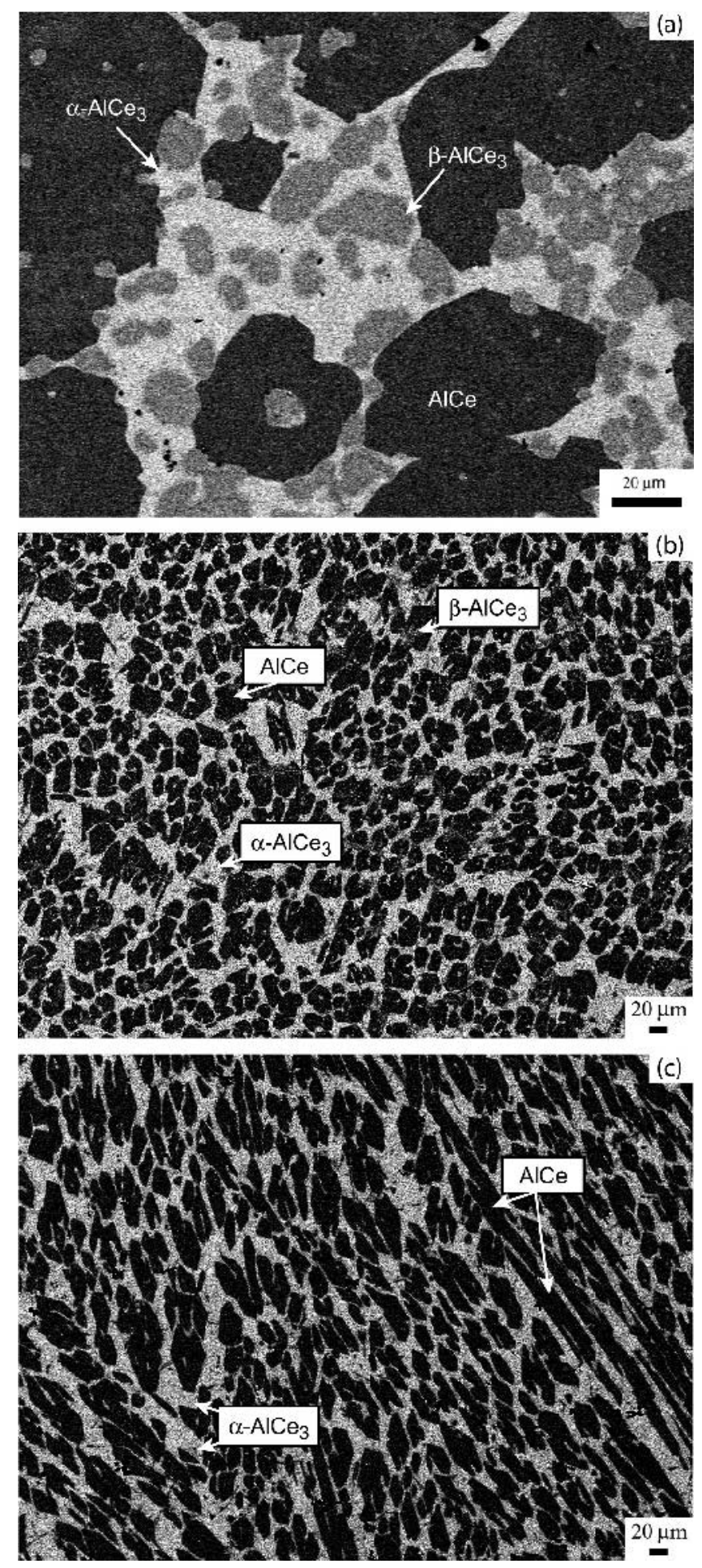

Fig. 5-Backscattering SEM micrographs of alloy $\mathrm{Al}_{40} \mathrm{Ce}_{60}$ after annealing at (a) $700{ }^{\circ} \mathrm{C}$, (b) $500{ }^{\circ} \mathrm{C}$, and (c) $200{ }^{\circ} \mathrm{C}$, for 10 days. Three phases are present in (a) and (b), i.e., $\mathrm{AlCe}, \alpha \mathrm{AlCe}_{3}$, and $\beta \mathrm{AlCe}_{3}$. There is a significant amount of $\beta \mathrm{AlCe}_{3}$ in (a), but very little in (b). Only AlCe and $\alpha \mathrm{AlCe}_{3}$ are present in (c). The $\mathrm{AlCe}_{2}$ phase is not retained in the microstructure after annealing at $700{ }^{\circ} \mathrm{C}$ for 10 days followed by quenching in cold water.

to the exchange-correlation functional. Reciprocal space (k-point) meshes are increased, to achieve convergence to a precision of $10 \mathrm{meV} / \mathrm{atm}$. All structures (both lattice parameters and atomic coordinates) are fully relaxed until, again, energies converge to a precision of $10 \mathrm{meV} / \mathrm{atm}$. The plane-
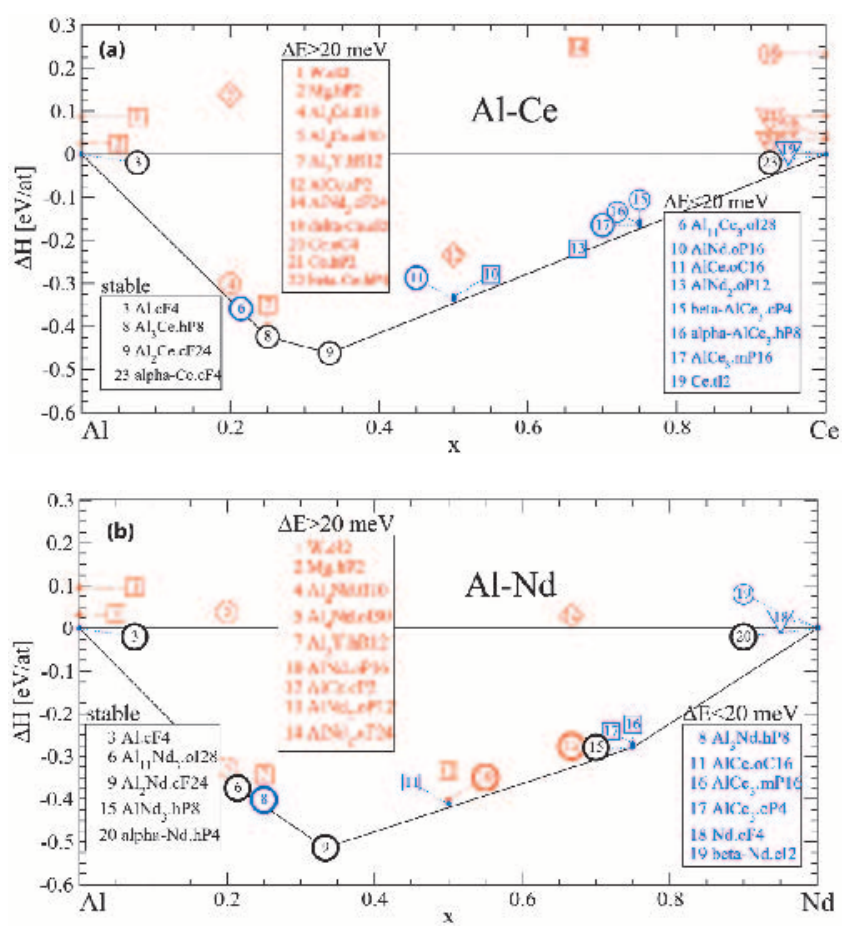

Fig. 6-Plots of heat of formation for (a) Al-Ce and (b) Al-Nd systems, calculated at $0 \mathrm{~K}$, using the VASP program. Refer to Table I for the exact values.

wave energy cutoff is held constant at $300 \mathrm{eV}$ for Al-Ce and at $253 \mathrm{eV}$ for $\mathrm{Al}-\mathrm{Nd}$, the defaults for the RE potentials. All calculations are performed using the "accurate" setting, which avoids wrap-around errors. Spin polarization is considered in all calculations other than pure aluminum. To obtain enthalpy of formation values $\Delta H_{f}$, a composition-weighted average of the pure elemental cohesive energies is subtracted from the cohesive energy of a given compound. The resulting energy is an enthalpy, because its volume is relaxed (at zero pressure). It is at $T=0 \mathrm{~K}$, because its atomic coordinates are relaxed.

Vertices of the convex hull of a scatter plot of $\Delta H_{f} v s$ composition identify stable structures. Points above the convex hull represent thermodynamically unstable structures, though they may be metastable, or stable, at higher temperatures, in some cases. Most of the structures examined are mechanically stable, in the sense that atomic displacements during relaxation are generally small (less than $0.03 \mathrm{~nm}$, at worst). The $\mathrm{Al}_{4}$ La.oI30-type structures have large displacements, because the starting crystallographic structure is not good. Details of the relaxed structures can be found on the WWW. ${ }^{[32]}$

The resulting enthalpies of formation are displayed in Figure 6; the enthalpy values are listed in Table I. The plotting symbol notation is: heavy circles for known stable, binary phases; light circles for known high-temperature phases; diamonds for known metastable phases; triangles for known high-pressure phases; and squares for imperfectly known, unknown, or hypothetical structures. Tie-lines run along convex hull edges, joining low-enthalpy structures at the vertices of the convex hull. Structures are labeled using the notation \{prototype $\} \cdot\{$ Pearson $\}$, where the prototype is the name of some commonly known isostructural compound; the Pearson 
Table I. Enthalpy of Formation of Stable Compound Phases, $\Delta H_{f}(\mathrm{~kJ} / \mathrm{mole}$ of atoms), at $0 \mathrm{~K}$ for Al-Ce and Al-Nd Systems Calculated by First Principles

\begin{tabular}{lcc}
\hline Compound (Type) & $\Delta H_{f}(\mathrm{Al}-\mathrm{Ce})$ & $\Delta H_{f}(\mathrm{Al}-\mathrm{Nd})$ \\
\hline $\mathrm{Al}_{4} \mathrm{RE}(t I l 0)$ & -29.1480 & -31.4637 \\
$\mathrm{Al}_{11} \mathrm{RE}_{3}(o I 28)$ & -34.6477 & -36.0853 \\
$\beta \mathrm{Al}_{3} \mathrm{RE}(h P 12)$ & -38.4492 & -38.0536 \\
$\alpha \mathrm{Al}_{3} \mathrm{RE}(h P 8)$ & -40.9192 & -38.7097 \\
$\mathrm{Al}_{2} \mathrm{RE}(c F 24)$ & -44.5952 & -49.5835 \\
$\mathrm{AlRE}(o C 16)$ & -32.5057 & -39.5973 \\
$\mathrm{AlRE}_{2}(o P 12)$ & -21.2170 & -26.6587 \\
$\beta \mathrm{AlCe}_{3}(c P 4)$ & -15.0130 & - \\
$\alpha \mathrm{AlRE}_{3}(h P 8)$ & -15.7849 & -26.9289 \\
\hline
\end{tabular}

symbol gives the point symmetry, the translational symmetry, and the number of sites per unit cell. For example, the structure in the Al-Ce binary diagram (Figure 6(a)), labeled $\mathrm{AlNd}_{2} . \mathrm{oP} 12$, contains $\mathrm{Al}$ and $\mathrm{Ce}$ atoms arranged as in $\mathrm{AlNd}_{2}$, with Ce substituting for $\mathrm{Nd}$. This structure is orthorhombic and primitive (no centering), with a 12-atom unit cell.

The binary phase diagrams are fairly well reproduced, but the overall level of agreement is lower than is found in similar studies of compounds not containing RE. ${ }^{[33]}$ The experimental phase diagrams of Al-Ce and $\mathrm{Al}-\mathrm{Nd}$ are quite similar to each other, as are the current calculated results. The discussion that follows addresses Al-Ce and Al-Nd simultaneously, starting from pure $\mathrm{Al}$ and ending with pure RE. For pure $\mathrm{Al}$, the comparison is made between fcc $(c F 4)$, hcp $(h P 2)$, and bcc $(c I 2)$ structures, finding the known fcc structure favored.

The low-temperature, stable $\alpha \mathrm{Al}_{11} \mathrm{RE}_{3} . o I 28$ phases are on the convex hull for $\mathrm{Al}-\mathrm{Nd}$, and are just $2 \mathrm{meV} /$ atom above for Al-Ce. The high-temperature $\beta$ phases with Pearson symbol $t I 10$ lie above the convex hulls by about $40 \mathrm{meV} /$ atom, in each case. According to the experimental phase diagrams, the composition of $\beta$ matches that of $\alpha,{ }^{[7,8,18]}$ but the ideal composition of $t I 10$ is more Al-rich than is oI28. Introducing an $\mathrm{Al}$ vacancy on the $4 \mathrm{e}$ site of $t I 10$ is found to raise the energy by an additional $40 \mathrm{meV} /$ atom (i.e., $400 \mathrm{meV} / \mathrm{vacancy}$ ) above the convex hull. Other sites are even more unfavorable. In the current thermodynamic modeling, the previously reported $\beta \mathrm{Al}_{11} \mathrm{RE}_{3}$ phase is corrected to be a stoichiometric $\mathrm{Al}_{4} \mathrm{RE}$ compound. Reports ${ }^{[34]}$ of $\mathrm{Al}_{4} \mathrm{RE}$ phases with structure type $o I 30$ (prototype $\mathrm{Al}_{4} \mathrm{La}$ ) are highly doubtful, because their enthalpies of formation are all found to be positive. There is thus no force driving the creation of such a crystal structure from its constituent elements.

The next two phases, $\mathrm{Al}_{3} \mathrm{Ce} . h P 8$ and $\mathrm{Al}_{2} \mathrm{Ce} . c F 24$, are correctly placed on the convex hull. As a candidate for the previously unreported structure $\beta \mathrm{Al}_{3} \mathrm{Ce} / \beta \mathrm{Al}_{3} \mathrm{Nd}$, the prototype $\mathrm{Al}_{3} \mathrm{Y} . h R 12$ is first considered. At a $\Delta E$ of around $20 \mathrm{meV} /$ atom, this could easily arise as a high-temperature phase. As suggested by Cacciamani and Ferro ${ }^{[18]}$ (Figure 1) the possibility of sublattice mixing in the $c F 24$ structures is explored. To test this possibility the compositions $\mathrm{Al}_{(1-x)} \mathrm{RE}_{x}(x=$ $0.292,0.333$, and 0.375 ) are investigated by taking a 24 -atom unit cell of $\mathrm{Al}_{2}$ RE.cF24 and replacing a single atom with one of the opposite type. The calculated energy cost is found to be around $1 \mathrm{eV}$ for each replacement. The estimation of entropy gains upon replacement from the numbers of available sites yields temperatures exceeding $4000 \mathrm{~K}$, at which sublattice disorder should be important. Since this temperature greatly exceeds the melting temperature, it is concluded that sublattice mixing can safely be ignored in these alloy systems.

For the RE-rich portions of the phase diagrams, numerous small disagreements are found between the calculation and the experiment. It is thought that this indicates an imperfect treatment of rare-earth atoms by current calculation methods. Some specific shortcomings are: (1) the use of an approximate exchange-correlation potential, despite the fact that tightly bound f-electrons may exhibit strong correlations; (2) the use of nonrelativistic equations for high-atomic-number elements; and (3) the assumption of collinear magnetism, even though RE often exhibit noncollinear magnetism.

At composition $x=0.5$, both experimental phase diagrams show stable phases. In both cases, calculations find that these phases lie slightly above the convex hulls. In the case of Al-Nd, calculations incorrectly find the AlCe.oC16 structure lower in energy than the AlNd.oP16. At composition $x=0.667$, both calculations find the $\mathrm{AlNd}_{2} . o P 12$ structure slightly above the convex hull. This structure is known to be stable even at low temperatures in Al-Nd. It is predicted that the observed high-temperature, stable compound $\mathrm{AlCe}_{2}$ should be isostructural to $\mathrm{AlNd}_{2}$. A reported ${ }^{[34]}$ metastable phase $\mathrm{AlNd}_{2}$ of structure $c F 24$ has positive enthalpy of formation and is probably an incorrect report.

At composition $\mathrm{AlCe}_{3}$, the established phase diagram shows a sequence of phases $(m C 16, h P 8$, and $c P 4)$ at progressively higher temperatures. Current energy data reproduces this sequence, but it is found that even the lowest energy lies slightly above the convex hull. In the case of Al$\mathrm{Nd}$, it is correctly determined that $\mathrm{AlNd}_{3} \cdot h P 8$ touches the convex hull.

Pure elemental Ce exhibits a complicated sequence of structures as temperature rises: $\alpha$ (fcc, low volume), $\beta$ ( $c P 4), \gamma$ (fcc, high volume), and $\delta$ (bcc). Because the cell volume is relaxed, the high-volume $\gamma$ phase is not found, but the others $(\alpha, \beta$, and $\delta$ ) are properly ordered in enthalpy. Likewise, the high-pressure phases lie correctly above the $\alpha$ phase in enthalpy. Although spin polarization is considered, current calculations for pure $\mathrm{Ce}$ did not find spin-polarized states, probably because the actual magnetic structures are spin canted in various ways. Pure elemental Nd exhibits only two phases, $\alpha(h P 4)$ and $\beta$ (bcc). Calculations place these in the proper sequence, and find the high-pressure fcc structure properly above $\alpha$.

\section{THERMODYNAMIC MODEL}

The Gibbs free energy of the individual phases is described by sublattice models ${ }^{[35]}$ and is defined relative to the stable element reference (SER), i.e., the enthalpies of the pure elements in their defined reference phase at $298.15 \mathrm{~K}$ and $1 \mathrm{~atm}$. All the disordered solutions, including the liquid, are modeled with a single sublattice, with the Gibbs energy expressed as for a binary phase with components $A$ and $B$ :

$$
\begin{aligned}
G^{\phi}= & x_{A}{ }^{o} G_{A}^{\phi}+x_{B}{ }^{o} G_{B}^{\phi}+\mathrm{R} T\left(x_{A} \ln x_{A}+x_{B} \ln x_{B}\right) \\
& +{ }^{e x} G^{\phi}+{ }^{\mathrm{mag}} G^{\phi}
\end{aligned}
$$

where ${ }^{o} G_{i}^{\phi}$ is the molar Gibbs energy of the pure element 
$i$ in the structure of phase $\phi$ in the nonmagnetic state, taken from the values tabulated by Dinsdale, ${ }^{[36]}$ and $x_{i}$ is the mole fraction of each component. The excess Gibbs energy is expressed in Redlich-Kister-Muggianu polynomial form: ${ }^{[37,38]}$

$$
{ }^{e x} G^{\phi}=x_{A} x_{B} \sum_{i}{ }^{i} L_{A, B}^{\phi}\left(x_{A}-x_{B}\right)^{i}
$$

The parameters ${ }^{i} L_{A, B}^{\phi}$ are the binary interaction parameters evaluated in the present work; this is typically modeled as ${ }^{i} L={ }^{i} a+{ }^{i} b T+{ }^{i} c T \ln (T)+{ }^{i} d T^{2}$. The magnetic contribution to the Gibbs energy $\left({ }^{\mathrm{mag}} G^{\phi}\right.$ ) for all binary compound phases is set to zero, because of a lack of experimental data.

Stoichiometric compounds are modeled as if the enthalpy and entropy are constants and only one element occupies one sublattice. For example, the Gibbs free energy for a binary stoichiometric compound $A_{x} B_{y}$ is modeled as $(\mathrm{J} / \mathrm{mole}$ of atoms)

$$
G^{A_{x} B_{y}}=\frac{x}{x+y}{ }^{o} G_{A}+\frac{y}{x+y}{ }^{o} G_{B}+a+b T
$$

The $\mathrm{C} 15$ Laves phase $A_{2} B\left(c F 24, \mathrm{Cu}_{2} \mathrm{Mg}\right)$ consists of only two crystallographic sites ( $A$ atoms occupy Wyckhoff sites $16 \mathrm{~d}$ and $B$ atoms occupy $8 \mathrm{a}$ ). Based on theoretical calculations and the fact that there is no experimental report on a solubility range in any $\mathrm{C} 15-\mathrm{Al}_{2} \mathrm{RE}$ compound in the $\mathrm{Al}-\mathrm{RE}$ binary system, ${ }^{[39,40]}$ a two-sublattice model $(A)_{2}(B)_{1}$ is a physically reasonable choice for modeling $\mathrm{C} 15-\mathrm{Al}_{2} \mathrm{RE}$ compounds, and there is no site substitution between $\mathrm{Al}$ and $\mathrm{RE}$ atoms in each sublattice. In fact, there are many other binary Laves phases (e.g., $\mathrm{Al}_{2} \mathrm{Ca}, \mathrm{Al}_{2} \mathrm{Hf}, \mathrm{Al}_{2} \mathrm{Sc}, \mathrm{Al}_{2} \mathrm{Zr}$, $\mathrm{CeCO}_{2}$, and $\mathrm{NdNi}_{2}$ ) that also do not exhibit a solubility range ${ }^{[39,40]}$ and they can be modeled as stoichiometric phases (e.g., $\left.\mathrm{Al}_{2} \mathrm{Ca}^{[41]}\right)$. But, it should be pointed out that many other Laves phases $\left(A_{2} B\right)$ do show appreciable solubility ranges (e.g., $\mathrm{Fe}_{2} \mathrm{Zr}$ and $\left.\mathrm{TaV}_{2}\right)$, and a sublattice model $(A, B)_{2}$ $(A, B)_{1}$ is commonly adopted to model their homogeneity range in the CALPHAD community. ${ }^{[18,42,43]}$ When combining the Al-RE binary systems and other binary systems that contain such $\mathrm{C} 15$ compounds (e.g., $\mathrm{C} 15-\mathrm{Al}_{2} \mathrm{~B}$ ) that show an appreciable homogeneity range for a multicomponent system, a sublattice model of $(\mathrm{Al}, B)_{2}(\mathrm{Al}, B, \mathrm{RE})_{1}$ or $(\mathrm{Al}, B, \mathrm{RE})_{2}$ $(\mathrm{Al}, B, \mathrm{RE})_{1}$ can be chosen. For example, Zinkevich et al. ${ }^{[43]}$ treated the $\mathrm{C} 15-\mathrm{Fe}_{2} \mathrm{Gd}$ and $\mathrm{C} 15-\mathrm{Fe}_{2} \mathrm{Zr}$ with a sublattice model of $(\mathrm{Fe}, \mathrm{Zr})_{2}(\mathrm{Fe}, \mathrm{Gd}, \mathrm{Zr})$ in the $\mathrm{Fe}-\mathrm{Gd}-\mathrm{Zr}$ ternary system, where $\mathrm{C} 15-\mathrm{Fe}_{2} \mathrm{Zr}$ shows an appreciable homogeneity range, while $\mathrm{C} 15-\mathrm{Fe}_{2} \mathrm{Gd}$ does not; the $\mathrm{Gd}$ atoms do not occupy the first sublattice site, because the $\mathrm{Gd}$ atomic radius is substantially larger than that of an $\mathrm{Fe}$ atom. ${ }^{[43]}$ Then, a set of thermodynamic parameters for the hypothetical lattices of $\mathrm{C} 15-\mathrm{Al}_{2} \mathrm{Al}$, $\mathrm{C} 15-\mathrm{RE}_{2} \mathrm{Al}$, and $\mathrm{C} 15-\mathrm{RE}_{2} \mathrm{RE}$ will be required, and ab-initio calculations would be ideally suited for such a purpose. Although there are some empirical parameters that are used for such hypothetical compounds, ${ }^{[18,20,42]}$ these parameters differ significantly from those that are determined from ab-initio calculations; ${ }^{[44]}$ consequently, the resulting phase diagrams often show exaggerated homogeneity ranges (compared with experiments). The current authors are investigating the thermodynamics of the hypothetical lattices of
$\mathrm{C} 15-\mathrm{Al}_{2} \mathrm{Al}, \mathrm{C} 15-\mathrm{RE}_{2} \mathrm{Al}$, and $\mathrm{C} 15-\mathrm{RE}_{2} \mathrm{RE}$, and the resulting Al-RE phase diagrams, based upon first-principles calculations; the results will be reported elsewhere.

\section{OPTIMIZATION RESULTS AND DISCUSSION}

The present optimization is primarily based on the experimental data both from this study and from the literature. For the DTA analysis, only the data from the heating segments are taken; the cooling segment is only used to assist DTA analysis. This is because DTA or DSC is always calibrated using the onset temperature during the melting process of high-purity standards. All the invariant reactions are characterized by their onset temperatures, and the liquidus temperatures are estimated by the final peak temperature. Further, it is found that $\mathrm{Ce}$ - and $\mathrm{Nd}$-rich alloys are prone to oxidation, especially in the liquid state. Therefore, the liquidus temperatures are set with a lower weight during optimization, with respect to the invariant reaction temperatures that are seen to be reproducible and, thus, more reliable.

Current experiments show that there is a new compound phase stable only at high temperatures $\left(648{ }^{\circ} \mathrm{C}\right.$ to $\left.755^{\circ} \mathrm{C}\right)$ in the Al-Ce system, and it is proposed to be $\mathrm{AlCe}_{2}(o P 12)$. The first-principle energy calculations reveal that it is just slightly above the convex hull at $0 \mathrm{~K}$, and can easily become stable at higher temperatures. From the DTA measurements, it is shown that there is a high probability that an $\alpha / \beta \mathrm{Al}_{3} \mathrm{Ce}$ polymorphous transition will occur at $973{ }^{\circ} \mathrm{C}$ in the $\mathrm{Al}-\mathrm{Ce}$ system and, likewise, that an $\alpha / \beta \mathrm{Al}_{3} \mathrm{Nd}$ transition will occur at $888{ }^{\circ} \mathrm{C}$ in the $\mathrm{Al}-\mathrm{Nd}$ system. It is proposed that the $\beta \mathrm{Al}_{3} \mathrm{RE}$ phase may be isostructural of the previously reported compound $\mathrm{Al}_{3} \mathrm{Y}(h P 12)$, and the first-principles energy calculations again show that $\beta \mathrm{Al}_{3} \mathrm{RE}(h P 12)$ is very likely stable at high temperatures. The $\mathrm{Al}_{4} \mathrm{RE}(t I 10)$ phase has previously been treated as $\beta \mathrm{Al}_{11} \mathrm{RE}_{3}(t I 10)$, under the assumption of $\mathrm{Al}$ deficiency via the vacancy mechanism. First-principles energy calculations show that vacancy substitution for $\mathrm{Al}$ sites is energetically costly and that, therefore, such a claim is physically unlikely. Indeed, current DSC measurements on the alloy $\mathrm{Al}_{11} \mathrm{Nd}_{3}$ (a nominal composition, its real chemistry possibly being close to $\mathrm{Al}_{79.5} \mathrm{Nd}_{20.5}$ ) resolved that $\mathrm{Al}_{11} \mathrm{Nd}_{3}$ (oI28) can be formed by a catetectic reaction $\mathrm{Al}_{4} \mathrm{Nd}$ $\leftrightarrow \mathrm{Liq}+\mathrm{Al}_{11} \mathrm{Nd}_{3}$ and a eutectoid reaction of $\mathrm{Al}_{4} \mathrm{Nd}+$ $\beta \mathrm{Al}_{3} \mathrm{Nd} \leftrightarrow \mathrm{Al}_{11} \mathrm{Nd}_{3}$. The former is associated with a large amount of heat and fast kinetics, because of the involvement of the liquid phase; it can, therefore, be easily detected by DTA and shown as a sharp peak in the DTA plots. In contrast, the latter is associated with a small amount of heat and possibly relatively slow kinetics; it can, therefore, only be detected by DSC measurements. Further, the invariant temperatures for these two reactions are fairly close, so that they can be easily misinterpreted. Although direct microstructural evidence is not achieved in this study, an in-situ X-ray diffraction or an in-situ transmission electron microscopy study would help to confirm its chemistry and crystal structure. Further, for alloys (such as $\mathrm{Al}_{65} \mathrm{Ce}_{35}$ ) that are close to $\mathrm{Al}_{2} \mathrm{Ce}$, DTA measurements do not support the phase diagram, ${ }^{[18]}$ since the solidus and the solvus were not detected. In fact, energy calculations predict that substitution between $\mathrm{Al}$ and $\mathrm{RE}$ atoms for $\mathrm{Al}_{2} \mathrm{RE}$ compounds can only occur at a temperature that is much higher than its congruent melting point. 
Therefore, it is physically reasonable to model it as a stoichiometric phase.

Most of the present DTA measurements agree with the results in previous reports, ${ }^{[5,8,9,10,17,21]}$ except for the reaction $\mathrm{Al}_{4} \mathrm{Ce}+\mathrm{Al}_{2} \mathrm{Ce} \leftrightarrow \mathrm{BAl}_{3} \mathrm{Ce}$, which occurs at $1192{ }^{\circ} \mathrm{C}$, but which was reported to occur at $1135{ }^{\circ} \mathrm{C}$. $^{[8]}$ Also, the current study places the eutectic reaction in the very Al-rich side, occurring at $641{ }^{\circ} \mathrm{C}$ with a eutectic point of $\sim 2.6$ at. pct Ce (Figure 2(a)). This eutectic point was reported as 4.0 at. pct $\mathrm{Ce}$ at $640{ }^{\circ} \mathrm{C},{ }^{[8]}$ and at 2.6 at. pct $\mathrm{Ce}$ at $633^{\circ} \mathrm{C}$. ${ }^{[10]}$ At $1006{ }^{\circ} \mathrm{C}$, the $\mathrm{Al}_{4} \mathrm{Ce}$ decomposes into a liquid and $\mathrm{Al}_{11} \mathrm{Ce}_{3}$. The $\mathrm{Al}_{11} \mathrm{Ce}_{3}$ is formed eutectoidally from $\mathrm{Al}_{4} \mathrm{Ce}$ and $\beta \mathrm{Al}_{3} \mathrm{Ce}$; the transformation temperature is not identified in this study, but is proposed to be at $1020{ }^{\circ} \mathrm{C}$, the $\alpha / \beta \mathrm{Al}_{11} \mathrm{Ce}_{3}$ transition temperature originally reported by Buschow. ${ }^{[8]}$ The $\mathrm{Al}_{2} \mathrm{Ce}$ is found to melt congruently at $1455{ }^{\circ} \mathrm{C}$, while it was reported as $1480{ }^{\circ} \mathrm{C} .{ }^{[8]}$ The reaction $\mathrm{Liq}+\mathrm{Al}_{2} \mathrm{Ce} \leftrightarrow \mathrm{AlCe}$ is now reported to occur at $\sim 855{ }^{\circ} \mathrm{C}$, while it was reported at $845^{\circ} \mathrm{C}$, but a small fluctuation in this transition temperature was seen in this study. The eutectic point of Liq $\leftrightarrow$ $\beta \mathrm{AlCe}_{3}+\gamma \mathrm{Ce}$ is now identified to be 90 at. pct $\mathrm{Ce}$ at $590{ }^{\circ} \mathrm{C}$. This finding is closer to what was reported as 89 at. pct $\mathrm{Ce}$ at $580{ }^{\circ} \mathrm{C},{ }^{[8]}$ than to what was reported as 86 at. pct $\mathrm{Ce}$ at $600{ }^{\circ} \mathrm{C}$. ${ }^{[17]}$

Based on these new measurements and other information from the literature, the Al-Ce system is optimized using the PARROT module. The thermodynamic parameters that were determined in this study for the Al-Ce system are listed in Table II. The calculated Al-Ce phase diagram is shown in Figure 7, and the experimental data, obtained from both the

Table II. Thermodynamic Parameters for Al-Ce System Optimized in This Study (Energy is in the Unit of $\mathrm{J} / \mathrm{mole}$ of Atoms)

\begin{tabular}{|c|c|c|}
\hline Phase & Parameters & Value \\
\hline Liquid & ${ }^{\circ} L_{\mathrm{Al}, \mathrm{Ce}}^{\text {liquid }}$ & $-130,371+38.523 \mathrm{~T}$ \\
\hline & ${ }^{1} L_{\mathrm{Al}, \mathrm{Ce}}^{\text {liquid }}$ & $-36,330+6.362 \mathrm{~T}$ \\
\hline & ${ }^{2} L_{\mathrm{Al}, \mathrm{Ce}}^{\text {liquid }}$ & $-9208+4.065 \mathrm{~T}$ \\
\hline Fcc-A1 & ${ }^{\mathrm{o}} L_{\mathrm{Al}, \mathrm{Ce}}^{\mathrm{fcc}}$ & $-62,851+30.556 \mathrm{~T}$ \\
\hline Bcc-A2 & ${ }^{\mathrm{o}} L_{\mathrm{Al}, \mathrm{Ce}}^{\mathrm{bcc}}$ & $-93,683+37.261 T$ \\
\hline $\mathrm{Al}_{4} \mathrm{Ce}$ & $G_{\mathrm{Al}: \mathrm{Ce}}^{\mathrm{Al}_{4} \mathrm{Ce}}-0.8^{\circ} G_{\mathrm{Al}}^{\mathrm{fcc}}-0.2^{\circ} G_{\mathrm{Ce}}^{\mathrm{fcc}}$ & $-29,557+2.001 T$ \\
\hline $\mathrm{Al}_{11} \mathrm{Ce}_{3}$ & $\begin{array}{l}G_{\mathrm{Al}: \mathrm{Ce}}^{\mathrm{Al}_{1} \mathrm{Ce}_{3}}-0.7857^{\circ} G_{\mathrm{Al}}^{\mathrm{fcc}} \\
\quad-0.2143^{\circ} G_{\mathrm{Ce}}^{\mathrm{fcc}}\end{array}$ & $-42,745+11.159 T$ \\
\hline$\beta \mathrm{Al}_{3} \mathrm{Ce}$ & $G_{\mathrm{Al}: \mathrm{Ce}}^{\beta \mathrm{Al}_{3} \mathrm{Ce}}-0.75^{\circ} G_{\mathrm{Al}}^{\mathrm{fcc}}-0.25^{\circ} G_{\mathrm{Ce}}^{\mathrm{fcc}}$ & $-44,437+9.867 T$ \\
\hline$\alpha \mathrm{Al}_{3} \mathrm{Ce}$ & $G_{\mathrm{Al}: \mathrm{Ce}}^{\alpha \mathrm{Al}_{3} \mathrm{Ce}}-0.75^{\circ} G_{\mathrm{Al}}^{\mathrm{fcc}}-0.25^{\circ} G_{\mathrm{Ce}}^{\mathrm{fcc}}$ & $-45,421+10.658 T$ \\
\hline $\mathrm{Al}_{2} \mathrm{Ce}$ & $\begin{array}{l}G_{\mathrm{Al}: \mathrm{Ce}}^{\mathrm{Al}_{2} \mathrm{Ce}}-0.6667^{\circ} G_{\mathrm{Al}}^{\mathrm{fcc}} \\
\quad-0.3333^{\circ} G_{\mathrm{Ce}}^{\mathrm{fcc}}\end{array}$ & $-50,060+9.889 T$ \\
\hline $\mathrm{AlCe}$ & $G_{\mathrm{Al}: \mathrm{Ce}}^{\mathrm{AlCe}}-0.5^{\mathrm{o}} G_{\mathrm{Al}}^{\mathrm{fcc}}-0.5^{\circ} G_{\mathrm{Ce}}^{\mathrm{fcc}}$ & $-48,000+14.468 T$ \\
\hline $\mathrm{AlCe}_{2}$ & $\begin{array}{l}G_{\mathrm{Al}: \mathrm{Ce}}^{\mathrm{AlCe}_{2}}-0.3333^{\circ} G_{\mathrm{Al}}^{\mathrm{fcc}} \\
\quad-0.6667^{\circ} G_{\mathrm{Ce}}^{\mathrm{fcc}}\end{array}$ & $-24,816+0.714 T$ \\
\hline$\beta \mathrm{AlCe}_{3}$ & $G_{\mathrm{Al}: \mathrm{Ce}}^{\beta \mathrm{AlC}_{3}}-0.25^{\circ} G_{\mathrm{Al}}^{\mathrm{fcc}}-0.75^{\circ} G_{\mathrm{Ce}}^{\mathrm{fcc}}$ & $-27,935+9.816 T$ \\
\hline$\alpha \mathrm{AlCe}_{3}$ & $G_{\mathrm{Al}: \mathrm{Ce}}^{\alpha \mathrm{AlCe}_{3}}-0.25^{\circ} G_{\mathrm{Al}}^{\mathrm{fcc}}-0.75^{\circ} G_{\mathrm{Ce}}^{\mathrm{fcc}}$ & $-28,226+10.372 T$ \\
\hline
\end{tabular}

literature and this study, including the invariant reaction and liquidus temperatures, are shown for comparison. The newly computed Al-Ce phase diagram agrees very well with the DTA data points, and excellent agreement for all the invariant reactions is achieved. On the other hand, the agreement of the computed liquidus boundary is good overall, but is less satisfactory; this may be due to: (1) the intrinsic uncertainty in terms of liquidus measurement; (2) the lack of sufficiently reliable thermodynamic measurements of the liquid phase; and (3) the high susceptibility to oxidation for RE-rich alloys. Figure 8(a) plots the enthalpy of mixing at $300 \mathrm{~K}$ with both the experimental data on the enthalpy formation of compound phases at $300 \mathrm{~K}$ and the values calculated from the first principles. The optimized enthalpy formation of all the compound phases agrees very well with the data determined experimentally, the error for which is about 2 to $3 \mathrm{~kJ} / \mathrm{mole}$ of atoms. ${ }^{[25,26]}$ On the other hand, the values calculated from the first principles agree reasonably well with the experimental ones, but only for $\mathrm{Al}_{4} \mathrm{Ce}, \mathrm{Al}_{11} \mathrm{Ce}_{3}$, and $\mathrm{Al}_{2} \mathrm{Ce}$. A large discrepancy for $\mathrm{AlCe}, \mathrm{AlCe}_{2}$, and $\mathrm{AlCe}_{3}$ is obvious, and is probably due to the previously mentioned difficulties involved in treating rare-earth elements. Figure 8(b) shows total enthalpy as a function of temperature for two alloys, namely, $\mathrm{Al}_{70} \mathrm{Ce}_{30}$ and $\mathrm{Al}_{40} \mathrm{Ce}_{60}$. All the first-order phase transitions can be recognized by a discontinuity of the total enthalpy at its particular transition temperature; this is indicated by a vertical dotted line on the figure. The calculated enthalpy change for the $\alpha / \beta \mathrm{AlCe}_{3}$ polymorphous phase transformation in $\mathrm{Al}_{40} \mathrm{Ce}_{60}$ is $\sim 0.1 \mathrm{~kJ} / \mathrm{mole}$ of atoms. This calculated value is very reasonable in the sense that this transformation was not detected by DSC, probably because the enthalpy change is so small. Quenching experiments showed that the kinetics are actually very fast for the $\alpha / \beta \mathrm{AlCe}_{3}$ transformation. For all the invariant reactions, it is also found that the calculated enthalpy

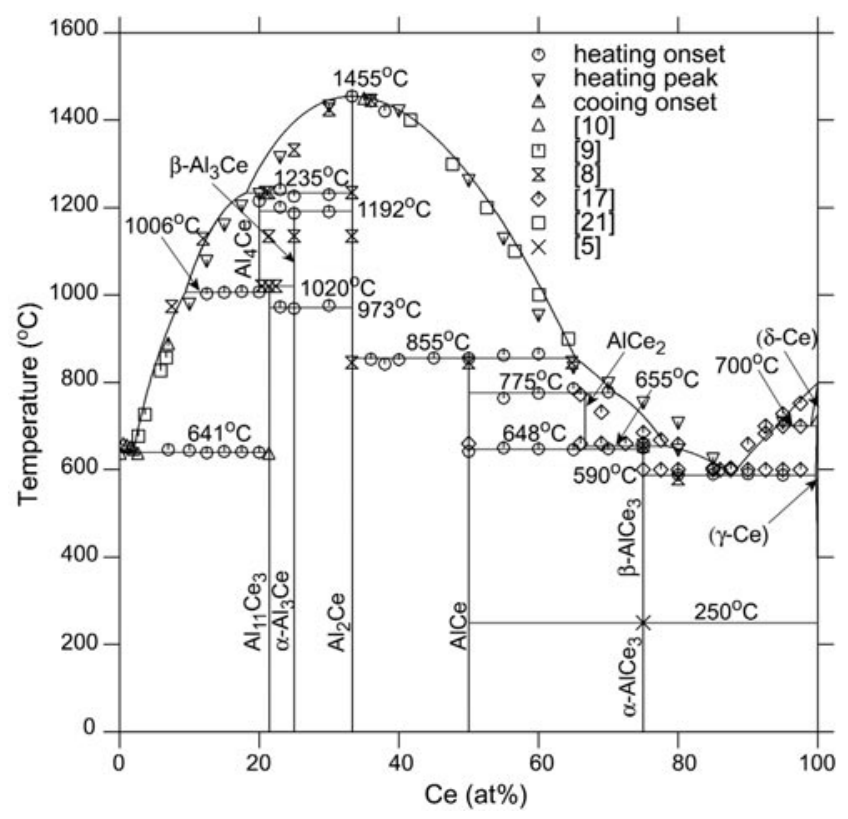

Fig. 7-The calculated Al-Ce binary phase diagram via the CALPHAD method, based on both the present study and information from the literature. The experimental thermal events are marked for comparison. The invariant temperatures marked on the phase diagram are obtained from experimental reports. 

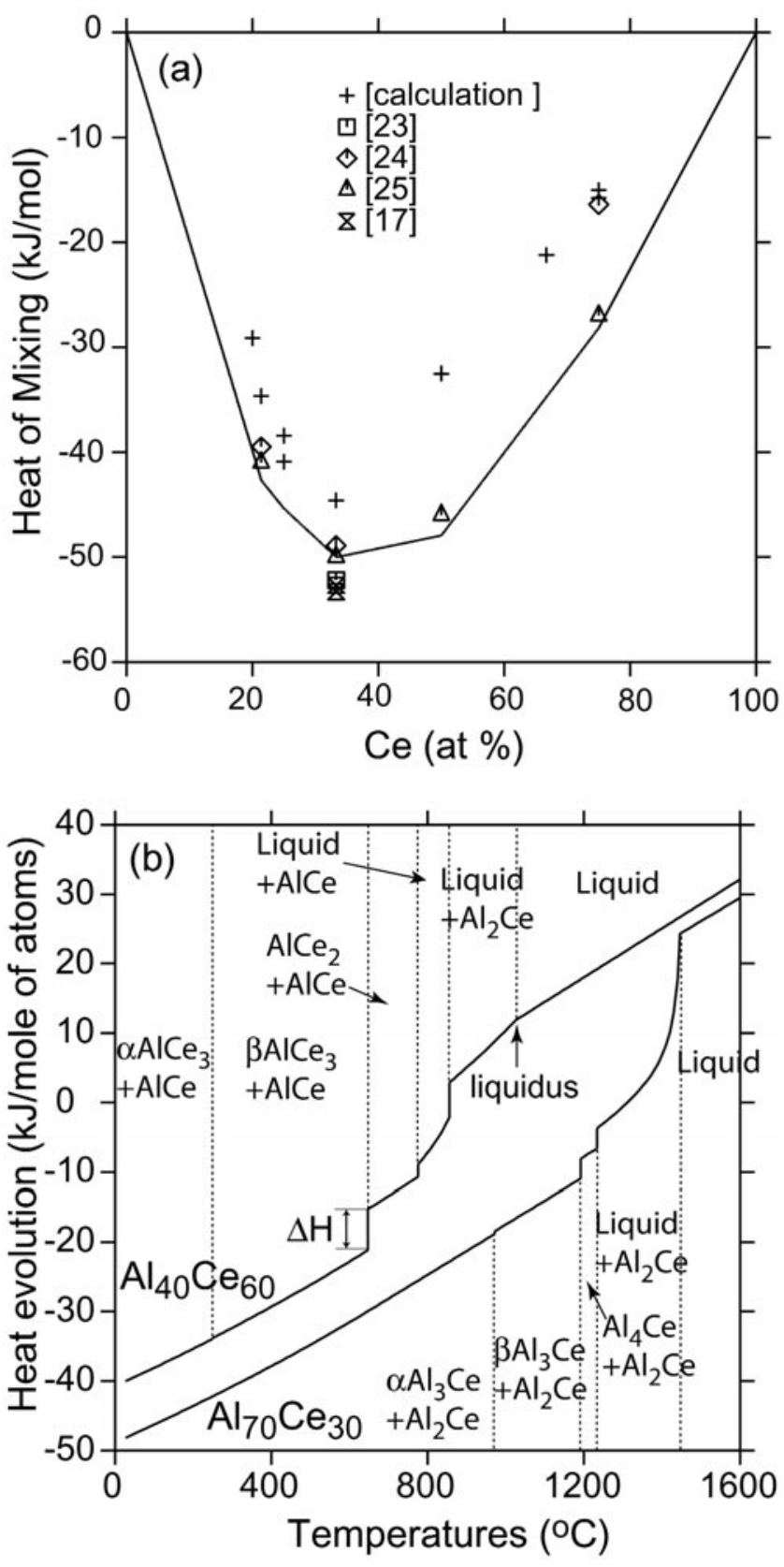

Fig. 8-(a) The calculated heat of mixing of Al-Ce alloys at $300 \mathrm{~K}$ via the CALPHAD method, based on both the present study and information from the literature. The enthalpy of the formation of the Al-Ce compound phases that was reported in the literature is marked for comparison, together with that calculated from first principles in this study (Table I). (b) The calculated enthalpy evolution of alloys $\mathrm{Al}_{40} \mathrm{Ce}_{60}$ and $\mathrm{Al}_{70} \mathrm{Ce}_{30}$ vs temperature. First-order phase transitions are recognized by the vertical discontinuity in enthalpy at the transition temperature (marked by the dotted lines), which is the heat associated for the reaction. The calculated total enthalpy change for each invariant reaction is in good agreement with those obtained from the DTA measurements for the same alloy (Fig. 3) on a relative scale. The phase fields separated by the invariant temperatures are also marked.

change is in very good agreement with the data obtained from the DTA measurements (obtained by the integrated area under the peak in the DTA plot) (Figure 3(a)), given the fact that the error in DTA enthalpy measurement is typically $\sim 20$ pct. Similar conclusions can be drawn for alloy $\mathrm{Al}_{40} \mathrm{Ce}_{60}$ and for other Al-Ce alloys.
Table III. Thermodynamic Parameters for Al-Nd System Obtained in This Study (Energy is in the Unit of $\mathrm{J} / \mathrm{mole}$ of Atoms)

\begin{tabular}{|c|c|c|}
\hline Phase & Parameters & Value \\
\hline \multirow[t]{3}{*}{ Liquid } & ${ }^{\circ} L_{\mathrm{Al}, \mathrm{Nd}}^{\text {liquid }}$ & $-159,238+57.514 T$ \\
\hline & ${ }^{1} L L$ liquid & $-1350-25.797 T$ \\
\hline & ${ }^{2} L_{\mathrm{Al}, \mathrm{Nd}}^{\text {liquid }}$ & $24,299-25.299 T$ \\
\hline \multirow[t]{2}{*}{ bcc- $A 2$} & ${ }^{\mathrm{o}} L_{\mathrm{Al}, \mathrm{Nd}}^{\mathrm{bcc}}$ & $-150,516+47.415 T$ \\
\hline & ${ }^{1} L_{\mathrm{Al}, \mathrm{Nd}}^{\mathrm{bcc}}$ & $-36,878$ \\
\hline \multirow[t]{2}{*}{ dhcp } & ${ }^{\mathrm{o}} L_{\mathrm{Al}, \mathrm{Nd}}^{\mathrm{dhcp}}$ & $-132,036+28.661 T$ \\
\hline & ${ }^{1} L_{\mathrm{Al}, \mathrm{Nd}}^{\mathrm{dhcp}}$ & $-61,094$ \\
\hline \multirow[t]{2}{*}{$\mathrm{Al}_{4} \mathrm{Nd}$} & $G_{\mathrm{Al}: \mathrm{Nd}}^{\mathrm{Al} \mathrm{Nd}}-0.8^{\mathrm{o}} G_{\mathrm{Al}}^{\mathrm{fcc}}$ & \\
\hline & $-0.2^{\circ} G_{\mathrm{Nd}}^{\mathrm{dhcp}}$ & $-30,097+1.365 T$ \\
\hline \multirow[t]{2}{*}{$\mathrm{Al}_{11} \mathrm{Nd}_{3}$} & $G_{\mathrm{Al}: \mathrm{Nd}}^{\mathrm{Al}_{1} \mathrm{Nd}_{3}}-0.7857^{\mathrm{o}} G_{\mathrm{Al}}^{\mathrm{fcc}}$ & \\
\hline & $-0.2143^{\circ} G_{\mathrm{Nd}}^{\mathrm{dhcp}}$ & $-39,355+7.72 T$ \\
\hline \multirow[t]{2}{*}{$\beta \mathrm{Al}_{3} \mathrm{Nd}$} & $G_{\mathrm{Al}: \mathrm{Nd}}^{\beta \mathrm{Al} \mathrm{l}^{\mathrm{Nd}}}-0.75^{\circ} G_{\mathrm{Al}}^{\mathrm{fcc}}$ & \\
\hline & $-0.25^{\circ} G_{\mathrm{Nd}}^{\mathrm{dhcp}}$ & $-43,229+8.022 T$ \\
\hline \multirow[t]{2}{*}{$\alpha \mathrm{Al}_{3} \mathrm{Nd}$} & $G_{\mathrm{Al}: \mathrm{Nd}}^{\alpha \mathrm{Al} N \mathrm{Nd}}-0.75^{\circ} G_{\mathrm{Al}}^{\mathrm{fcc}}$ & \\
\hline & $-0.25^{\circ} G_{\mathrm{Nd}}^{\mathrm{dhcp}}$ & $-45,046+9.587 T$ \\
\hline \multirow[t]{2}{*}{$\mathrm{Al}_{2} \mathrm{Nd}$} & $G_{\mathrm{Al}: \mathrm{Nd}}^{\mathrm{Al} \mathrm{Nd}}-0.6667^{\mathrm{o}} G_{\mathrm{Al}}^{\mathrm{fcc}}$ & \\
\hline & $-0.3333^{\circ} G_{\mathrm{Nd}}^{\mathrm{dhcp}}$ & $-54,037+11.622 T$ \\
\hline \multirow[t]{2}{*}{ AlNd } & $G_{\mathrm{Al}: \mathrm{Nd}}^{\mathrm{AlNd}}-0.5^{\circ} G_{\mathrm{Al}}^{\mathrm{fcc}}$ & \\
\hline & $-0.5^{\mathrm{o}} G_{\mathrm{Nd}}^{\mathrm{dhcp}}$ & $-51,110+15.354 T$ \\
\hline \multirow[t]{2}{*}{$\mathrm{AlNd}_{2}$} & $G_{\mathrm{Al}: \mathrm{Nd}}^{\mathrm{AlNd}_{2}}-0.3333^{\circ} G_{\mathrm{Al}}^{\mathrm{fcc}}$ & \\
\hline & $-0.6667^{\circ} G_{\mathrm{Nd}}^{\mathrm{dhcp}}$ & $-35,858+10.073 T$ \\
\hline \multirow[t]{2}{*}{$\mathrm{AlNd}_{3}$} & $G_{\mathrm{Al}: \mathrm{Nd}}^{\mathrm{AlNd}_{3}}-0.25^{\circ} G_{\mathrm{Al}}^{\mathrm{fcc}}$ & \\
\hline & $-0.75^{\circ} G_{\mathrm{Nd}}^{\mathrm{dhcp}}$ & $-27,788+7.208 T$ \\
\hline
\end{tabular}

Concerning the Al-Nd system, DTA measurements were performed on seven Al-rich alloys. A eutectic reaction Liq $\leftrightarrow$ $\mathrm{Al}+\mathrm{Al}_{11} \mathrm{Nd}_{3}$ occurs at $641{ }^{\circ} \mathrm{C}$, and the reaction $\mathrm{Al}_{4} \mathrm{Nd} \leftrightarrow$ $\mathrm{Liq}+\mathrm{Al}_{11} \mathrm{Nd}_{3}$ occurs at $934{ }^{\circ} \mathrm{C}$. The thermodynamic parameters that were determined in this study for the Al-Nd system are listed in Table III; the calculated Al-Nd phase diagram is shown in Figure 9, with all the DTA data points marked for comparison. Again, excellent agreement between the calculated invariant reactions and those determined experimentally is achieved, except for the liquidus of the Nd-rich portion. The $\mathrm{AlNd}_{3}$ phase was reported to melt peritectically at $675{ }^{\circ} \mathrm{C}^{[7]}$ and at $780{ }^{\circ} \mathrm{C} \cdot{ }^{[17]}$ Saccone et al. ${ }^{[17]}$ also proposed a eutectoid reaction of $\beta \mathrm{Nd} \leftrightarrow \alpha \mathrm{Nd}+\mathrm{AlNd}_{3}$ at $650{ }^{\circ} \mathrm{C}$, and a eutectic reaction of $\mathrm{Liq} \leftrightarrow \beta \mathrm{Nd}+\mathrm{AlNd}_{3}$ at $690{ }^{\circ} \mathrm{C}$, with a eutectic point of 81 at. pct $\mathrm{Nd}$. The present findings are that the reactions $\mathrm{AlNd}_{2}+\mathrm{Liq} \leftrightarrow \mathrm{AlNd}_{3}$ and $\mathrm{Liq} \leftrightarrow \beta \mathrm{Nd}+\mathrm{AlNd}_{3}$, together with a very narrow temperature range of the liquid $+\mathrm{AlNd}_{2}$ phase field, cannot be fulfilled simultaneously. Indeed, in Cacciamani's assessment, ${ }^{[18]}$ the reaction $\mathrm{Liq} \leftrightarrow \beta \mathrm{Nd}+\mathrm{AlNd}_{3}$ was optimized to occur at $727{ }^{\circ} \mathrm{C}\left(37^{\circ} \mathrm{C}\right.$ higher than the experimental value $^{[17]}$ ), with a eutectic point of 82.8 at. pct Nd. Here, the assessment is that $\mathrm{AlNd}_{2}$ melts congruently. All the nearby invariant reaction temperatures are fulfilled very well. The calculated heat of mixing for Al-Nd alloys at $300 \mathrm{~K}$ and the measured enthalpy of formation for Al-Nd compound 
phases at $300 \mathrm{~K}$ are presented in Figure 10(a), and the agreement with the experimental values is quite good, within the experimental errors. As was the case in the Al-Ce binary system, the values calculated from first principles agree rea-

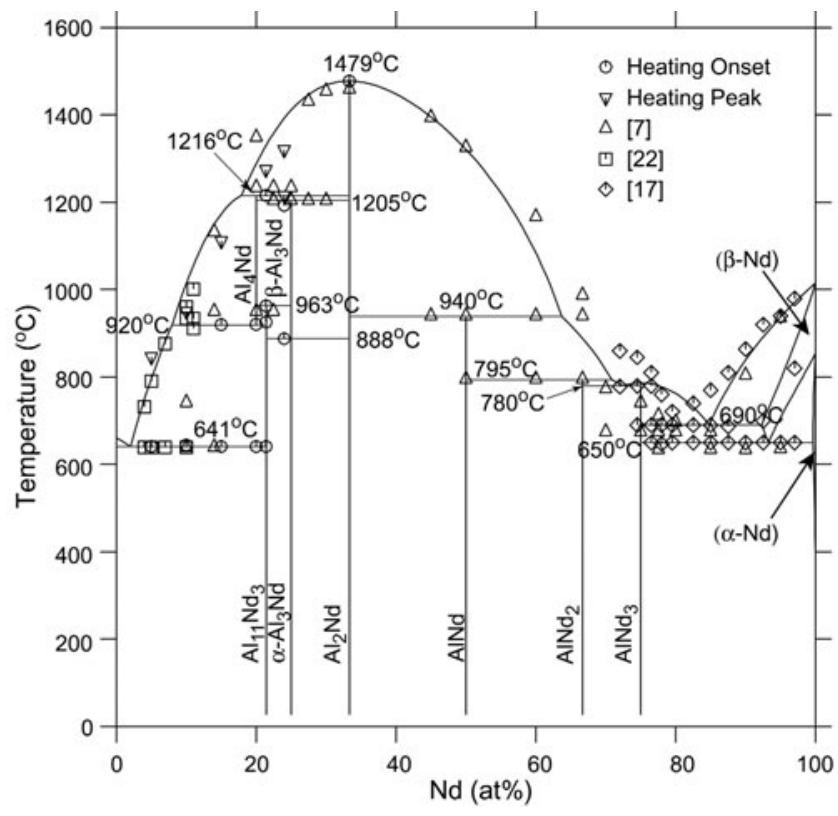

Fig. 9-The calculated Al-Nd binary phase diagram via the CALPHAD method, based on both the present study and information from the literature, with experimental thermal events marked for comparison. The invariant temperatures determined from experiments are also marked. sonably well with experimental values only for the Al-rich compounds, namely, $\mathrm{Al}_{4} \mathrm{Nd}, \mathrm{Al}_{11} \mathrm{Nd}_{3}$, and $\mathrm{Al}_{2} \mathrm{Nd}$. For the $\mathrm{Nd}$-rich compounds, the calculated values are significantly higher (toward the more positive direction) than the experimental ones. Figure 10(b) shows total enthalpy as a function of temperature for two compositions: $\mathrm{Al}_{79.5} \mathrm{Nd}_{20.5}$ and $\mathrm{Al}_{76} \mathrm{Nd}_{24}$. The $\mathrm{Al}_{79.5} \mathrm{Nd}_{20.5}$ was selected because alloy $\mathrm{Al}_{11} \mathrm{Nd}_{3}$ has an actual chemistry close to this composition. If compared with the enthalpy changes obtained from the DSC/DTA measurements (Figure 4), all the calculated data are very reasonable, although there is no experimental report on the enthalpy of formation for the $\mathrm{Al}_{4} \mathrm{Nd}$ phase.

In the present study, the first-principles energy calculations have been helpful in verifying the sublattice model of the $\mathrm{Al}_{2} \mathrm{RE}(c F 24)$ phase, both in predicting the stability of the $\mathrm{AlCe}_{2}(o P 12)$ and $\beta \mathrm{Al}_{3} \mathrm{RE}(h P 12)$ phases, particularly since microstructural evidence is not available, and in examining the phase relationship between $\mathrm{Al}_{4} \mathrm{RE}$ and $\mathrm{Al}_{11} \mathrm{RE}_{3}$. All these theoretical results provide confidence in this experimental investigation, validating a CALPHAD model that is physically grounded. Also, the enthalpy of formation for compound phases directly calculated from first principles can be immediately integrated into the CALPHAD methodology. Such integration will become valuable in cases where the experimental information is absent. Further, the integration decreases the number of variables to be optimized, thus improving the accuracy of the CALPHAD modeling in principle. In fact, such ideas have been implemented by Kaufman et al. ${ }^{[45]}$ to predict the Cr-Ta-W ternary phase diagram, and by Wolverton, ${ }^{[46,47]}$ to study phase metastability and phase equilibrium in commercial Al alloys.
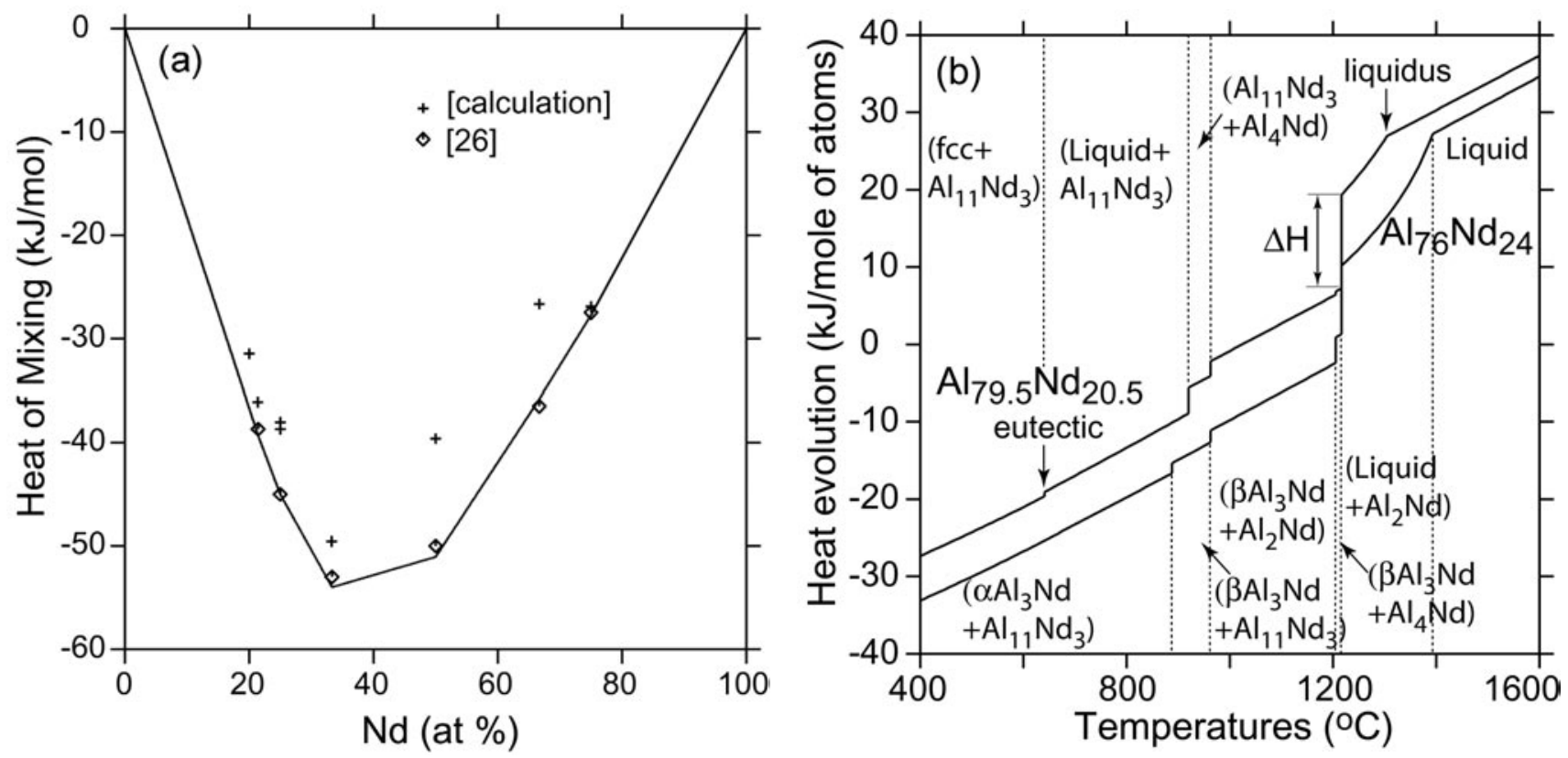

Fig. 10-(a) The calculated heat of mixing of Al-Nd alloys at $300 \mathrm{~K}$ via the CALPHAD method, based on both the present study and information from the literature. The data for the enthalpy of the formation of the Al-Nd compound phases that were reported in Ref. 26 are marked for comparison, together with those calculated from first principles in this study (Table I). (b) The calculated total enthalpy evolution of alloys $\mathrm{Al}_{79.5} \mathrm{Nd}_{20.5}$ and $\mathrm{Al}_{76} \mathrm{Nd}_{24} v s$ temperature. First-order phase transitions are recognized by the vertical discontinuity in enthalpy at the transition temperature (marked by the dotted lines), which is the heat associated for the reaction. The calculated total enthalpy change for each invariant reaction is in good agreement with the heat obtained from the DTA measurements for the same alloy (Fig. 4) on a relative scale. The phase fields separated by the invariant temperatures are also marked. 


\section{CONCLUSIONS}

The Al-Ce and Al-Nd systems were reinvestigated using first-principles energy calculations and critical experiments. The following new conclusions were reached.

1. An equilibrium-phase $\mathrm{AlCe}_{2}$ exists and is stable at high temperatures $\left(647{ }^{\circ} \mathrm{C}\right.$ to $\left.775{ }^{\circ} \mathrm{C}\right)$. Its structure is likely $o P 12$.

2. The previously described $\beta \mathrm{Al}_{11} \mathrm{RE}_{3}(\mathrm{RE}=\mathrm{La}, \mathrm{Ce}, \mathrm{Nd}$, or Pr) should ideally have a stoichiometry of $\mathrm{Al}_{4} \mathrm{RE}(t I 10)$.

3. There exists an $\alpha / \beta \mathrm{Al}_{3} \mathrm{Ce}$ polymorphous transition that occurs at $973{ }^{\circ} \mathrm{C}$ in the Al-Ce system and an $\alpha / \beta \mathrm{Al}_{3} \mathrm{Nd}$ polymorphous transition that occurs at $888{ }^{\circ} \mathrm{C}$ in the $\mathrm{Al}-\mathrm{Nd}$ system. The $\beta \mathrm{Al}_{3} \mathrm{RE}$ phase may be isostructural with $\beta \mathrm{Al}_{3} \mathrm{Y}(h P 12)$.

4. The $c F 24$ structures of $\mathrm{Al}_{2} \mathrm{Ce}$ and $\mathrm{Al}_{2} \mathrm{Nd}$ should be treated as stoichiometric compound phases.

5. The $\alpha / \beta \mathrm{AlCe}_{3}$ polymorphous transition is confirmed, but the exact transition temperature (between $200{ }^{\circ} \mathrm{C}$ to $500{ }^{\circ} \mathrm{C}$ ) is not identified.

6. The invariant temperatures detected during the heat segment, rather than the liquidus temperatures, were emphasized during optimization. The former are always easier to identify during thermal analysis and thus are of higher accuracy and reproducibility. Therefore, they should be assigned more weight during optimization;

7. Both the Al-Ce and Al-Nd systems were thermodynamically reoptimized. The calculated heat (absorbed or released) for all the invariant reactions agrees well with data from thermal measurements on a relative scale.

\section{ACKNOWLEDGMENTS}

The authors acknowledge financial support from the MultiUniversity Research Initiative (Grant No. F49602-01-1-0352) and from NDF Grant DMR-0111198 and in part from the Computational Materials Science Network, a program of the Office of Science, United States Department of Energy. One of the authors (MCG) is indebted to A.D. Rollett for his unlimited support during the preparation of this manuscript. MCG also thanks C. Qiu for valuable discussions on CALPHAD database development and for commenting on this manuscript; he also like to thanks G. Cacciamani for providing both the assessed experimental data file for the AlCe system and the assessed databases for the Al-Ce, Al-Nd, and Al- La systems. The authors acknowledge inspiring and useful discussions with T.D. Massalski and Y. Wang.

\section{REFERENCES}

1. Y. He, S.J. Poon, and G.J. Shiflet: Science, 1988, vol. 241, pp. 1640-42

2. A. Inoue, K. Ohtera, and T. Masumoto: Jpn. J. Appl. Phys., 1988, vol. 27, pp. L736-39.

3. W. Biltz and H. Pieper: Z. Anorg. Chem., 1924, vol. 134, p. 13.

4. G. Canneri and A. Rossi: Gazz. Chim. Ital., 1932, vol. 62, pp. 202-11.

5. J.H.N. van Vucht: Z. Metallkd., 1957, vol. 48, p. 253.

6. K.H.J. Buschow and J.H.N. van Vucht: Philips Res. Rep., 1965, vol. 20, pp. 337-48.

7. K.H.J. Buschow: J. Less-Common Met., 1965, vol. 9, pp. 452-56.

8. K.H.J. Buschow and J.H.N. van Vucht: Z. Metallkd., 1966, vol. 57, pp. $162-66$.
9. L.F. Yamshchikov, V.A. Lebedev, I.F. Nichkov, S.P. Raspopin, and O.K. Kokoulin: Izv. Vyssh Uchebn. Zaved., Tsv. Metall., 1980, vol. 5, pp. 50-54.

10. V.I. Kononenko and S.V. Golubev: Izv. Akad Nauk SSSR, Met., 1990, vol. 2, pp. 197-99.

11. N. Clavaguera and Y. Du: J. Phase Equilibrium, 1996, vol. 17, pp. 107-11.

12. J. Wang: CALPHAD, 1996, vol. 20, pp. 135-38.

13. G.B. Kale, A. Biswas, and I.G. Sharma: Scripta Mater., 1997, vol. 37, pp. 999-1003.

14. A.H. Gowes De Mesquita and K.H.J. Buschow: Acta Crystallogr., 1967, vol. 22, pp. 497-501.

15. M. Baricco, F. Gaetner, G. Cacciamani, P. Rizzi, L. Battezzati, and A.L. Greer: Mater. Sci. Forum, 1998, vols. 269-272, pp. 553-58.

16. L. Battezzati, M. Barcicco, and C. Antonione: J. Alloys Compounds, 1994, vol. 209, pp. 341-49.

17. A. Saccone, A.M. Cardinale, S. Delfino, and R. Ferro: Z. Metallkd., 1996, vol. 87, pp. 82-87.

18. G. Cacciamani and R. Ferro: CALPHAD, 2001, vol. 25, pp. 583-97.

19. A.M. Cardinale, G. Cacciamani, G. Borzone, and R. Ferro: CALPHAD, 2003, vol. 27, pp. 221-26.

20. G. Cacciamani., A.M. Cardinale, G. Borzone, and R. Ferro: CALPHAD, 2003, vol. 27, pp. 227-33.

21. K.A. Gschneidner, Jr. and F.W. Calderwood: Bull. Alloy Phase Diagrams, 1988, vol. 9, pp. 669-72.

22. T. Godecke, W. Sun, R. Luck, and K. Lu: Z. Metallkd., 2001, vol. 92, pp. 723-30.

23. C. Colinet, A. Pasturel, and K.H.J. Buschow: J. Chem. Thermodyn., 1985, vol. 17, pp. 1133-39.

24. F. Sommer and M. Keita: J. Less-Common Met., 1987, vol. 136, pp. 95-99.

25. G. Borzone, G.Cacciamani, and R. Ferro: Metall. Trans. A, 1991, vol. 22A, pp. 2119-23.

26. G. Borzone, A.M. Cardinale, G. Cacciamani, and R. Ferro: Z. Metallkd., 1993, vol. 84, pp. 635-40.

27. B. Sundman, B. Jansson, and J.-O. Andersson: CALPHAD, 1985, vol. 9 , pp. $153-90$

28. G. Kresse and J. Hafner: Phys. Rev. B, 1993, vol. 47, pp. 558-61.

29. G. Kresse and J. Furthmuller: Phys. Rev. B, 1996, vol. 54, pp. 1169-86.

30. G. Kresse and D. Joubert: Phys. Rev. B, 1999, vol. 59, pp. 1758-75.

31. J.P. Perdew, K. Burke, and M. Ermzerhoff: Phys. Rev. Lett., 1996, vol. 77, pp. 3865-68.

32. WWW site http://alloy.phys.cmu.edu (special "published" entries).

33. M. Mihalkovic and M. Widom: Phys. Rev. B, 2004, vol. 70, pp. 144107-144119.

34. P. Villars: Pearson's Handbook, Desk Edition, ASM, Metals Park, $\mathrm{OH}, 1997$.

35. M. Hillert and L.I. Staffanson: Acta Chem. Scand., 1970, vol. 24, pp. 3618-26.

36. A.T. Dinsdale: CALPHAD, 1991, vol. 15 , pp. $317-425$

37. O. Redlich and A.T. Kister: Ind. Eng. Chem., 1948, vol. 40, p. 345.

38. Y.M. Muggianu, M. Gambino, and J.P. Bros: J. Chim. Phys., 1975, vol. 22, pp. 83-88.

39. T.B. Massalski, H. Okamoto, P.R. Subramanian, and L. Kacprzak: Binary Alloy Phase Diagrams, ASM INTERNATIONAL, Materials Park, OH, 1990.

40. H. Okamoto: Desk Handbook: Phase Diagrams for Binary Alloys, ASM INTERNATIONAL, Materials Park, OH, 2000.

41. K. Ozturk, L.Q. Chen, and Z.K. Liu: J. Alloys Compounds, 2002, vol. 340 , pp. 199-206.

42. I. Ansara, T.G. Chart, A. Fernandez Guillermet, F.H. Hayes, U.R. Kattner, D.G. Pettifor, N. Saunders, and K. Zeng: CALPHAD, 1997, vol. 21, pp. 171-218.

43. M. Zinkevich, N. Mattern, and I. Bacher: Z. Metallkd. 2002, vol. 93, pp. 186-98

44. K. Ozturk, Y. Zhong, L.Q. Chen, C. Wolverton, J.O. Sofo, and Z.K. Liu: Metall. Mater. Trans. A, 2005, vol. 36A, pp. 5-13.

45. L. Kaufman, P.E.A. Turchi, W. Huang, and Z.-K. Liu: CALPHAD, 2001, vol. 25, pp. 419-33.

46. C. Wolverton: Acta Mater., 2001, vol. 49, pp. 3129-42.

47. C. Wolverton, X.-Y. Yan, R. Vijayaraghavan, and V. Ozolin: Acta Mater., 2002, vol. 50, pp. 2187-97. 